EVALUATING THE CONVERSION OF EMPLOYMENT AREAS

By

Oliver Rojas

Civil Engineering, Universidad Metropolitana, 2007

\author{
A Major Research Paper \\ Presented to Ryerson University \\ In partial fulfillment of the requirements for the degree of \\ Master of Planning \\ In \\ Urban Development
}

Toronto, Ontario, Canada, 2017

(C) Oliver Rojas 2017 


\section{Author's Declaration}

I hereby declare that I am the sole author of this MRP. This is a true copy of the MRP, including any required final revisions.

I authorize Ryerson University to lend this MRP to other institutions or individuals for the purpose of scholarly research.

I further authorize Ryerson University to reproduce this MRP by photocopying or by other means, in total or in part, at the request of other institutions or individuals for the purpose of scholarly research.

I understand that my MRP may be made electronically available to the public. 


\title{
EVALUATING THE CONVERSION OF EMPLOYMENT AREAS
}

\author{
(C) Oliver Rojas 2017 \\ Master of Planning \\ in \\ Urban Development \\ Ryerson University
}

\begin{abstract}
Toronto is a thriving city where growth is occurring amid challenges of affordability and lack of space. Tensions are arising as the result of competing interests and are evidenced in the struggle of competing land uses. In fact, employment areas in former industrial districts are becoming increasingly threatened by this relentless growth. Many developers find these areas attractive for mixed use developments; however, the City of Toronto is making efforts to protect them from these uses to keep them exclusively for economic and business activity.
\end{abstract}

This paper proposes a guideline to evaluate conversion proposals. It draws from relevant literature and similar cases to assess through a questionnaire approach the worthiness of future proposals for conversion. The intention is that any member of a community can reach a conclusion based on his or her answers to the guideline.

Key words: Employment areas, conversion, guideline, development application 


\section{Acknowledgements}

Thanks to Dr. Christopher De Sousa for his dedication and meaningful contribution to the content of this research. Also, I thank Dr. Pamela Robinson for her encouragement throughout this program. 


\section{Dedication}

To God for giving me strength and wisdom

To my Wife, for her support and patience during these challenging times 


\section{Table of Contents}

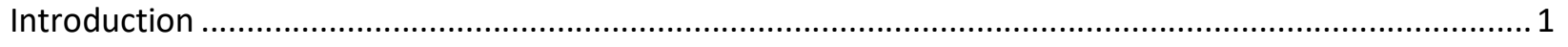

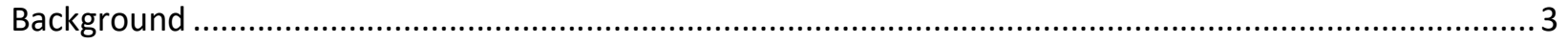

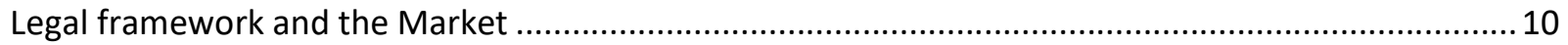

Economic Value of Employment Areas ......................................................................... 12

Supply and Demand of Employment Lands ................................................................... 13

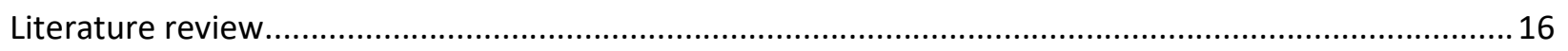

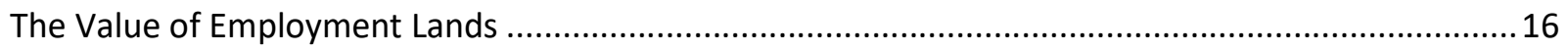

Decision Making Methods and criteria development ......................................................... 17

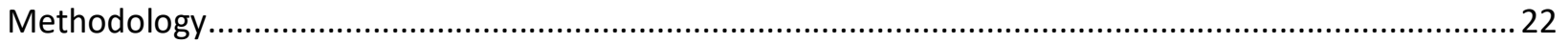

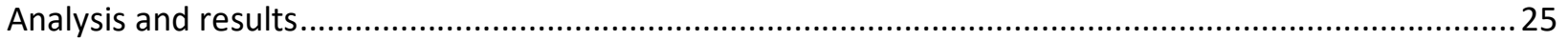

Criteria that discourages re-designation from employment areas to other designations ..................28

Criteria that encourage a re-designation from employment areas to other designations ..................29

Criteria that could lead to, or discourage conversion from employment areas to other designation... 30

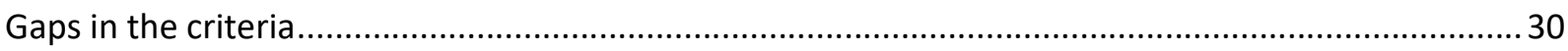

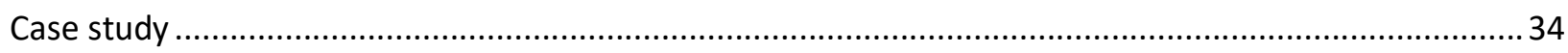

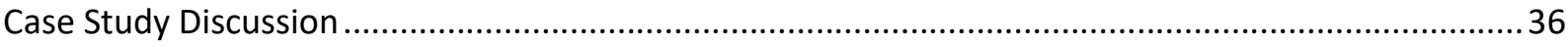

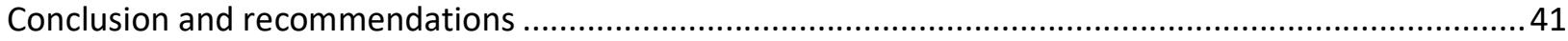

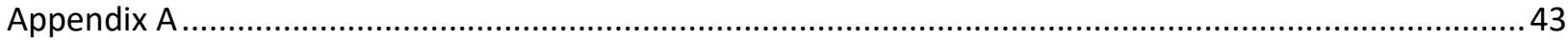

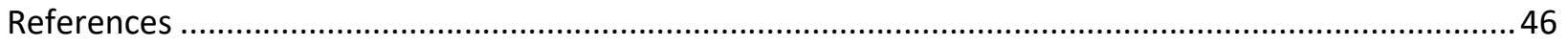




\section{List of Figures}

Figure 1. Map of Employment lands .......................................................................................... 5

Figure 2 - Value of Non-Residential Building Permits in the Greater Golden Horseshoe...........................6

Figure 3 - Ground-Related MLS Housing Sales and Housing Starts, GTA, 1996-2015 .............................. 6

Figure 4 - Requests or Applications to Convert Employment Lands as of February 2014........................ 9

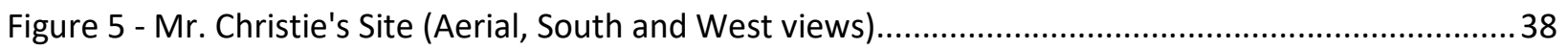




\section{List of Tables}

Table 1 - Labour force by Industry - Toronto and Etobicoke ............................................................. 4

Table 2 - Land Needs and Supply by Functionality ..................................................................... 15

Table 3 - Importance of factors in influencing business site selection decisions ...................................19

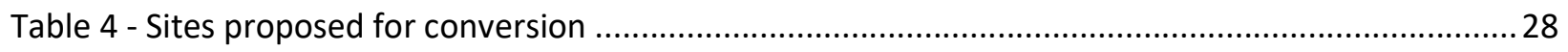

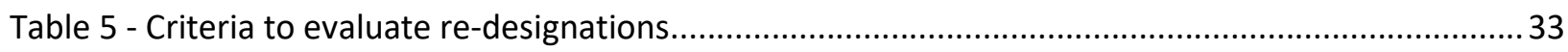




\section{Introduction}

Toronto is a rapidly growing city. Within the period from 2006 to 2011, the city experienced a growth of 9.2 per cent (Ontario Ministry of Finance, 2012). This growth is a reflection of the popularity of this city as a place that provides good jobs and quality of life. According to The Economist Intelligence Unit, Toronto is ranked as the fourth most liveable city in the world, behind Vancouver, Vienna and Melbourne (The Economist , 2016). The strong economy and quality of life are also highlighted by another report issued by PWC (2016) that ranks Toronto as $1^{\text {st }}$ in quality of living (PwC, 2016).

This success also spills to the employment sector. According to the same report from PWC, Toronto is ranked third as the best city to do business, third in the best intellectual capital and innovation, third in transportation and infrastructure, third in health, safety and security and third in technology readiness (PwC, 2016). In turn, industrial spaces have become under pressure. According to the Toronto Real Estate Board, there has been a $20 \%$ increase in lease rates of industrial spaces from 2006 to 2016 (Toronto Real Estate Board, 2016). Also, vacancy rates at less than $3 \%$ are indicative of the strong demand for these areas (Avison Young, 2016).

Additionally, this success is also entailing demand for residential units. Since 2011 the average selling price of a home in the Greater Toronto/Hamilton Area has been consistently increasing. In 2011 the average price of a home was $\$ 465,014$ but in 2016 , the average price of a home reached a value of $\$ 729,917$ (Toronto Real Estate Board, 2017). Consequently, this demand is also getting transferred to non-residential areas, in particular, employment areas. Some of these employment areas, seemingly abandoned or vacant, are usually chosen by developers because of their proximity to the main city and existing infrastructure that could be reutilized or readapted to accommodate residential uses.

While re-adaptation of employment areas could be costly, new site remediation technologies still makes the endeavour of developing these areas attractive and feasible. However, this also comes at a cost that is often overlooked, which is the loss of employment areas as places where businesses can operate and bring not only jobs but also revenues to fund other services within the municipal structure. Therefore, deciding the fate of these lands is no easy task; in fact, it requires careful analysis of multiple factors.

Apart from the submittal requirements and checklists posted on the City of Toronto's website, there is very little information on what elements planners take into consideration when faced with the decision of converting or retaining employment areas. This paper aims to help in this decision process. It attempts to list the aspects that should be considered based on a thorough review of literature and best practices and provides a guideline to assist in the decision process. This would allow developers, planners and residents to better foresee the possible 
outcomes of future attempts to convert employment lands. The research also examines the gaps in current planning practice in relation to evaluating conversions and fills them based on research from authors that have previously studied this problem. Finally, a current site, whose owner has applied for conversion, has been chosen as a case study to test the effectiveness of the guideline.

At this time in Toronto's stage, this research seeks to contribute to the dialog about a topic that continues to gain more relevance in an environment of competing interests. The paper is addressed not only to an academic and professional audience, but also to residents with little knowledge of city planning; all this with the intention of helping them make an informed opinion and be part of the city building process. 


\section{Background}

Employment areas are locations that, as per official planning documents, are destined to support activities of economic nature such as manufacturing and warehousing. In order to analyze the employment areas situation, it is pertinent to contextualize the problem within important facts about Toronto and particularly Etobicoke as our area of interest. To begin with, Toronto is a city that, according to the last economic report issued in 2016 , had a population of 2,826,498 people (City of Toronto, 2016). South Etobicoke, the area considered in this paper's case study had 58,995 people in 2011, around 3.6\% more than in 2006 (City of Toronto, 2014). More recently, according to the latest census results from Statistics Canada the area shows a population of 67,565 people, over $14 \%$ more than in 2011 (Statistics Canada, 2017).

South Etobicoke has been experiencing important changes during the past decade. The area was home to many motels located adjacent to Lake Ontario. Population growth and an attractive landscape provided by its proximity to the lake made these areas a prime target for mixed use development. A secondary plan for the Motel Strip and urban design guidelines implemented by the City of Toronto through the Humber Bay Shore's study, have turned a former motel area into a highly demanded mixed use waterfront development (McGinnis, 2012). The age breakdown of the latest 2016 census data is still unknown, but if the 2011 population trends continue, young adults and seniors will bring new service demands and challenges to adjacent employment areas.

Toronto is home to many different industry sectors, each one of them contributing more or less to the overall success of the city's Gross Domestic Product (GDP), which in 2015, was around \$160 billion and was expected to grow by 3\% in 2016 (City of Toronto, 2016). Some of these industry sectors are: Design, Education Services, Fashion, Financial Services, Food and Beverage, Green, Life Sciences, Music, Technology and Tourism (City of Toronto, 2016).

In terms of labour force, a survey done by Statistics Canada in 2011 reveals the top 5 industries that provide employment to residents in Toronto and Etobicoke (City of Toronto, 2014). It is important to note that manufacturing, transportation and warehousing are among the most important industry sectors in Etobicoke, providing $16.6 \%$ of the total percentage of employment; however, in the City of Toronto Economic Annual Summary for 2015, it was reported that, although full time employment grew $1.35 \%$ in 2015 compared to 2014 , employment in the manufacturing sector decreased (City of Toronto, 2015). 
Labour Force by Industry

\begin{tabular}{|lrr|}
\hline \multicolumn{2}{|c|}{ Etobicoke York } & No. \\
\hline & 595 & 0.2 \\
\cline { 2 - 3 } Agriculture, forestry, fishing and hunting & 370 & 0.1 \\
Mining and oil and gas extraction & 1,645 & 0.5 \\
Utilities & 22,555 & 7.2 \\
Construction & 34,005 & 10.9 \\
Manufacturing & 14,870 & 4.8 \\
Wholesale trade & 32,765 & 10.5 \\
Retail trade & 17,705 & 5.7 \\
Transportation and warehousing & 10,630 & 3.4 \\
Information and cultural industries & 20,080 & 6.4 \\
Finance and insurance & 7,570 & 2.4 \\
Real estate and rental and leasing & 26,835 & 8.6 \\
Professional, scientific \& technical services & 425 & 0.1 \\
Management of companies and enterprises & 19,375 & 6.2 \\
Admin. \& support, waste mgmt. \& remediation & 21,835 & 7.0 \\
Educational services & 27,730 & 8.9 \\
Health care and social assistance & 6,850 & 2.2 \\
Arts, entertainment and recreation & 18,005 & 5.8 \\
Accommodation and food services & 14,500 & 4.7 \\
Other services (except public administration) & 13,430 & 4.3 \\
Public administration & 311,775 & 100.0 \\
Total & &
\end{tabular}

\begin{tabular}{|lrr|}
\hline \multicolumn{2}{|c|}{ City of Toronto } & No. \\
& & $\%$ \\
\cline { 2 - 3 } Agriculture, forestry, fishing and hunting & 1,940 & 0.1 \\
Mining and oil and gas extraction & 2,355 & 0.2 \\
Utilities & 7,260 & 0.5 \\
Construction & 64,910 & 4.8 \\
Manufacturing & 109,465 & 8.1 \\
Wholesale trade & 57,710 & 4.3 \\
Retail trade & 133,235 & 9.9 \\
Transportation and warehousing & 51,340 & 3.8 \\
Information and cultural industries & 62,860 & 4.7 \\
Finance and insurance & 112,415 & 8.3 \\
Real estate and rental and leasing & 35,215 & 2.6 \\
Professional, scientific \& technical services & 155,440 & 11.5 \\
Management of companies and enterprises & 1,975 & 0.1 \\
Admin. \& support, waste mgmt. \& remediation & 72,620 & 5.4 \\
Educational services & 100,865 & 7.5 \\
Health care and social assistance & 131,520 & 9.7 \\
Arts, entertainment and recreation & 32,250 & 2.4 \\
Accommodation and food services & 88,300 & 6.5 \\
Other services (except public administration) & 67,380 & 5.0 \\
Public administration & 60,145 & 4.5 \\
\cline { 2 - 3 } Total & $1,349,200$ & 100.0 \\
\hline
\end{tabular}

Table 1 - Labour force by Industry - Toronto and Etobicoke

Before understanding the industrial land use in Toronto, it is necessary to assess the situation of the industrial sector in the city. In an annual summary presented to the Economic Development Committee of Toronto in 2015, important details about the manufacturing situation were presented. First, on a positive note, the report indicates improvement in the export figures. In detail, the amount of exports in billions of dollars increased from 2014 to 2015 by $13.59 \%$. The most important industry players and their figures were Transportation and Equipment manufacturing with $\$ 76.82$ billion, Chemical Manufacturing with $\$ 20.7$ billion and Machinery Manufacturing with \$17.64 billion (City of Toronto, 2015).

Second, in terms of jobs, there seems to be a decline in jobs related to the manufacturing sector. In particular, there were 124,609 jobs in manufacturing and warehousing within Toronto but the report also mentions that from 2004 to 2014 there was a reduction of $26.4 \%$ in jobs related to this sector; $60.8 \%$ of that decline was experienced by the clothing manufacturing subsector. This may be driven by the influence of technology and low cost shipping from other parts of the world. (Moffat, 2016).

Third, in terms of land, Toronto's industrial land inventory is large in size but seems to be experiencing pressure from residential demand and an evolving industry where manufacturing continues to decrease. The Economic Dashboard points to Toronto having the "largest industrial land inventory in North America" (City of Toronto, 2015), with 252,906,910 square feet of space installed (City of Toronto, 2016). However, according to the Greater Toronto Area Industrial Market Report, the vacancy rates shown by the industrial land market are under 3\% (Avison Young, 2016). 


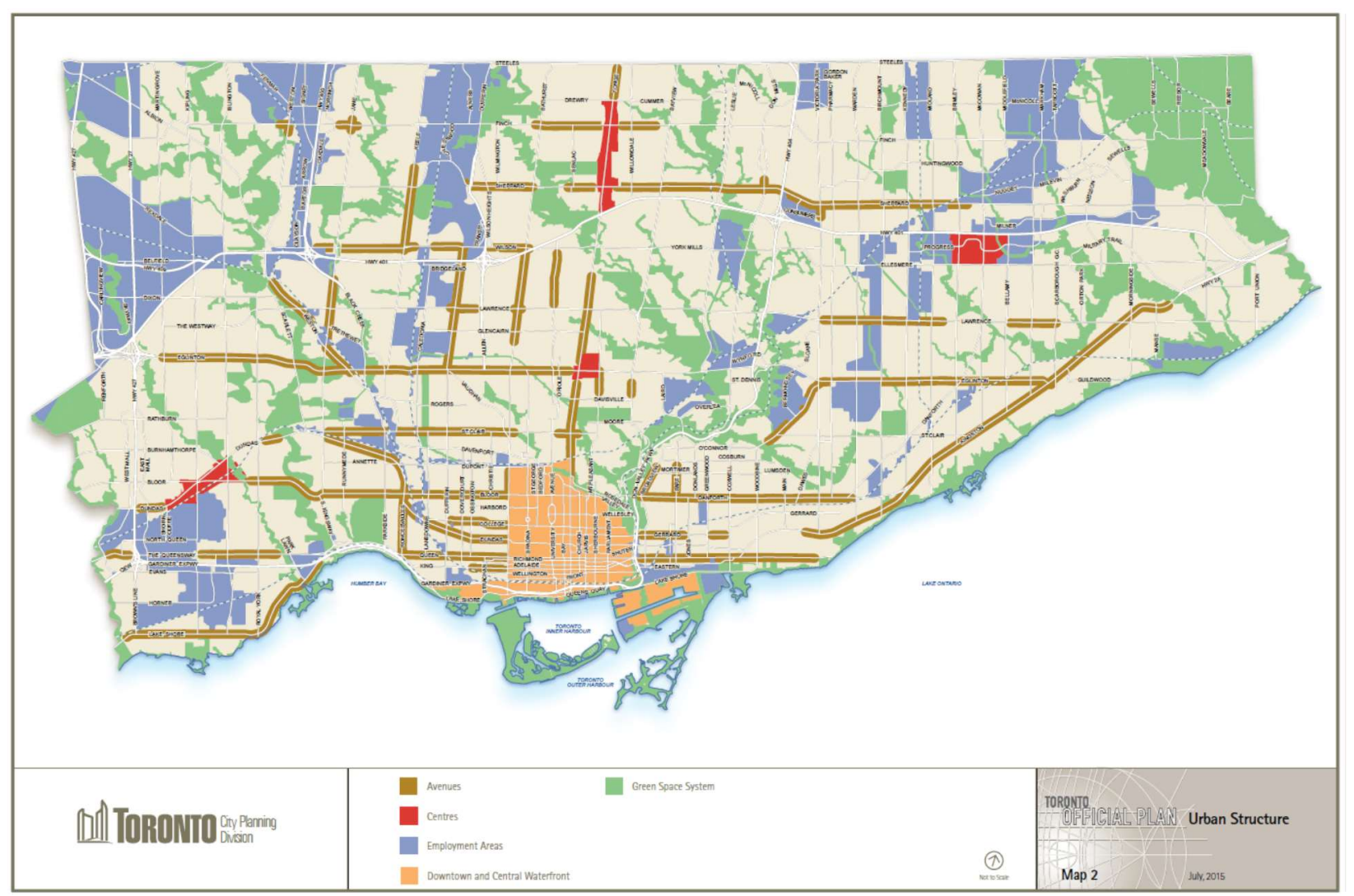

Figure 1. Map of Employment lands

While vacancy rates seem quite low, there also seems to be a slowing trend in the issuance of non-residential building permits within the Greater Golden Horseshoe. As it can be observed in the figure below, the value of these permits has been hovering around the $\$ 2$ billion mark since the third quarter of 2011 and actually dropped below that mark in the third quarter of 2016. 
Figure 1:

Value of Non-Residential Building Permits in the Greater Golden Horseshoe*, 2011-2016

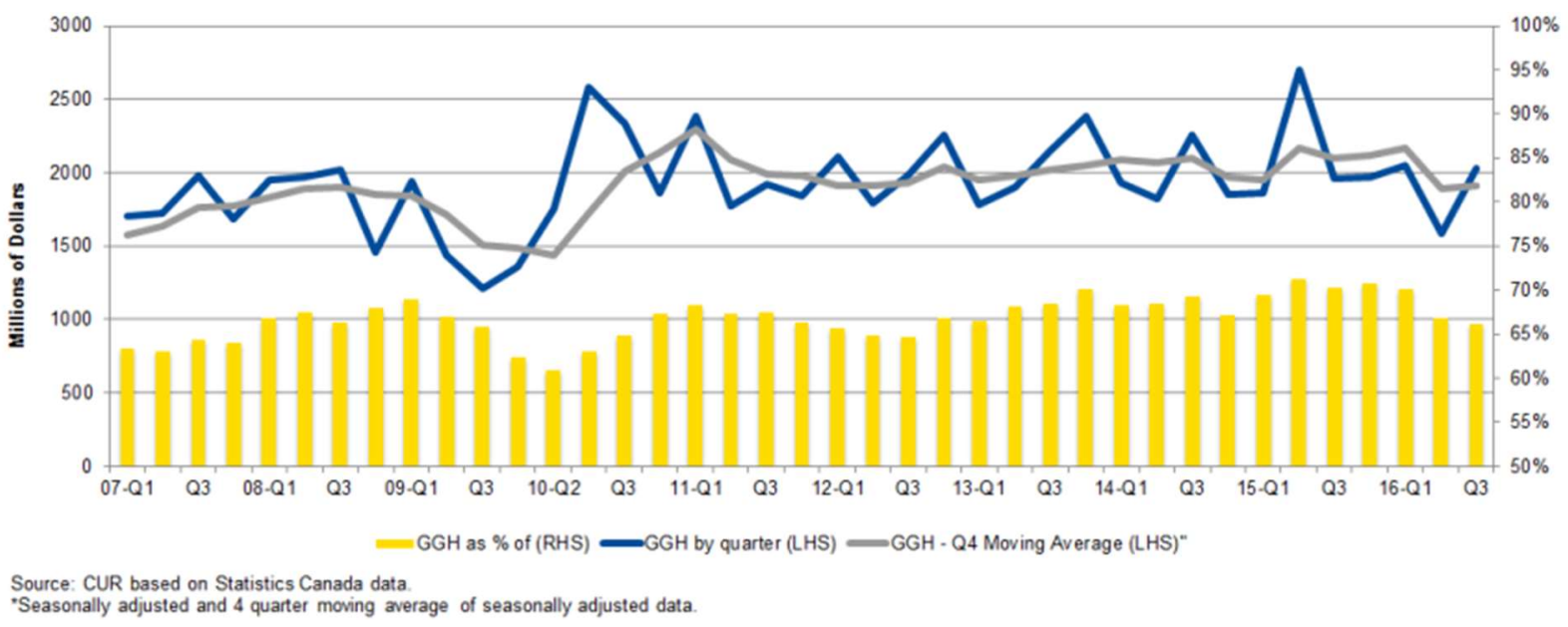

Figure 2 - Value of Non-Residential Building Permits in the Greater Golden Horseshoe

Notable is the pressure exerted by the residential sector. As it can be noticed in the image below, while home sales seem to increase year over year, the number of housing starts appear stagnant (Amborski, 2016). This could contribute to an upward pressure in home prices and the demand for lots. In fact, Clayton (2015) identified the lack of serviced land to build ground- related residential units as insufficient to cope with the existing demand of the market (Clayton, 2015).

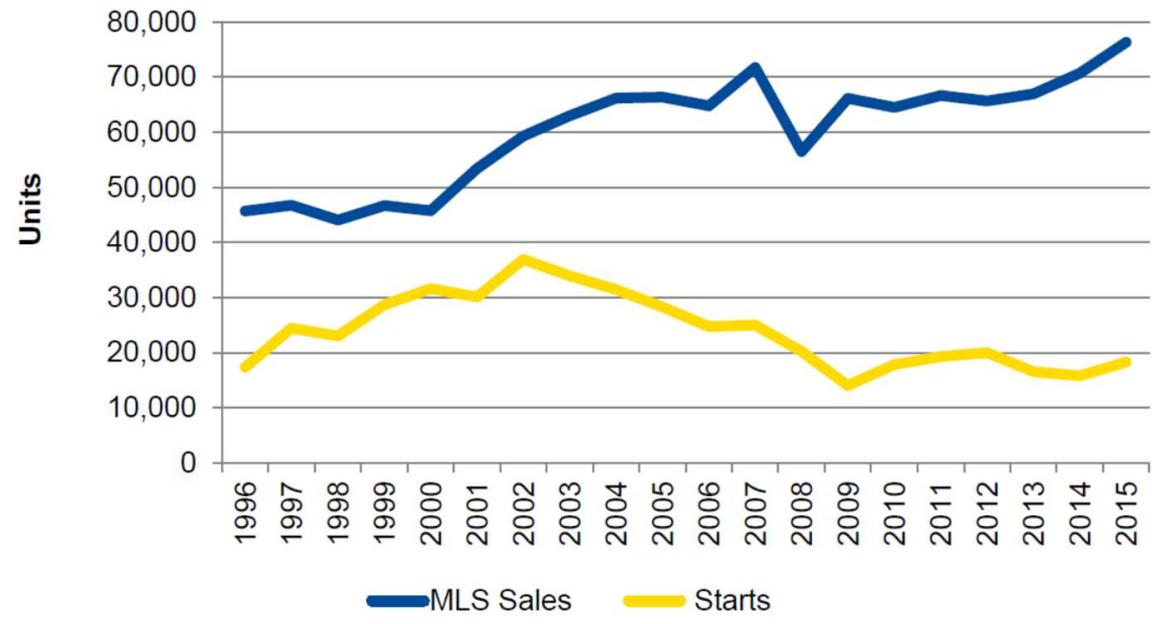

*Ground-related homes: single-and semi-detached dwellings and townhouses. Source: CUR based on data from CMHC and TREB.

Figure 3 - Ground-Related MLS Housing Sales and Housing Starts, GTA, 1996-2015 
A stagnant demand for lands for industrial use together with a rising demand of residential units and low availability of land to build them is drawing the attention to seemingly abandoned industrial sites that could serve different purposes. The map of figure 4 shows employment areas within the City of Toronto that were requested to be converted from Employment Areas to other uses in the last municipal comprehensive review. Together, they represent close to 400 hectares of land (refer to figure 4 on page 8 ).

A quick exploration of notable Toronto cases reveals tensions between different sectors that are not easy to reconcile. One case in point is a dispute between planners at the City of Toronto, Nestle Canada and Castlepoint Studio Partners Ltd in the development of 158, 164, 181, and 200 Sterling Road. This application for an Official Plan amendment that sought to allow residential and commercial uses on the site was initially refused, mostly because of issues of incompatibility with the surrounding area.

Further, Nestle argued that a residential development would compromise their operation due to potential future complains of noise and odours. On the other hand, the developer argued that after multiple consultations, the community have come to accept the project. Further they have committed to consider future retrofitting costs of the industrial site as a result of the introduction of residential uses in the adjacencies of an industrial site (Alamenciak, 2012). The redevelopment project was taken to the Ontario Municipal Board (OMB) and approved on May, 2013; but it demonstrates the progressive gains that non-industrial uses achieve on industrial areas. But this is not always the case.

Other industrial sites have had to adapt themselves to non industrial adjacent uses. The Redpath Sugar refinery at Queens Quay is another example of resistance to competing uses. The owners have invested millions of dollars in technology to reduce noise and odours originated from their operations. This has kept nearby workers and residents at bay when it comes to nuisances generated by industrial sites (Grant, 2011) .

These examples show competing interests in which their owners have genuine intentions and rights to their properties and businesses. But they also show that, in order to ensure the sustainability of economic activity, hard and uncomfortable decisions based on policy must be taken.

The Strategic Plan for Accelerating Economic Growth and Job Creation in Toronto is a document that provides a set of recommendations to encourage economic prosperity. Some of the recommendations emerge as a recognition to competing interests for land. Recommendation B1 clearly points at this issue and calls for assuring enough land to accommodate employment growth in the industrial and commercial sector (City of Toronto, 2013). 
While Clayton (2015) points to the Ontario land use legislation as being responsible for a lack of land available to build residential units and contributing to the pressure on industrial land, a review of these pieces of legislation demonstrate that there are also good policy elements that seek to protect them from these pressures (Clayton, 2015). Therefore, it is critical to identify the documents that embody Ontario's planning regulation in order to understand how they play their part in shaping the way our city grows, namely:

- Ontario Planning Act

- Provincial Policy Statement

- Growth Plan for the Greater Golden Horseshoe

- The City of Toronto Official Plan

- $\quad$ The City of Toronto Zoning By-Laws 


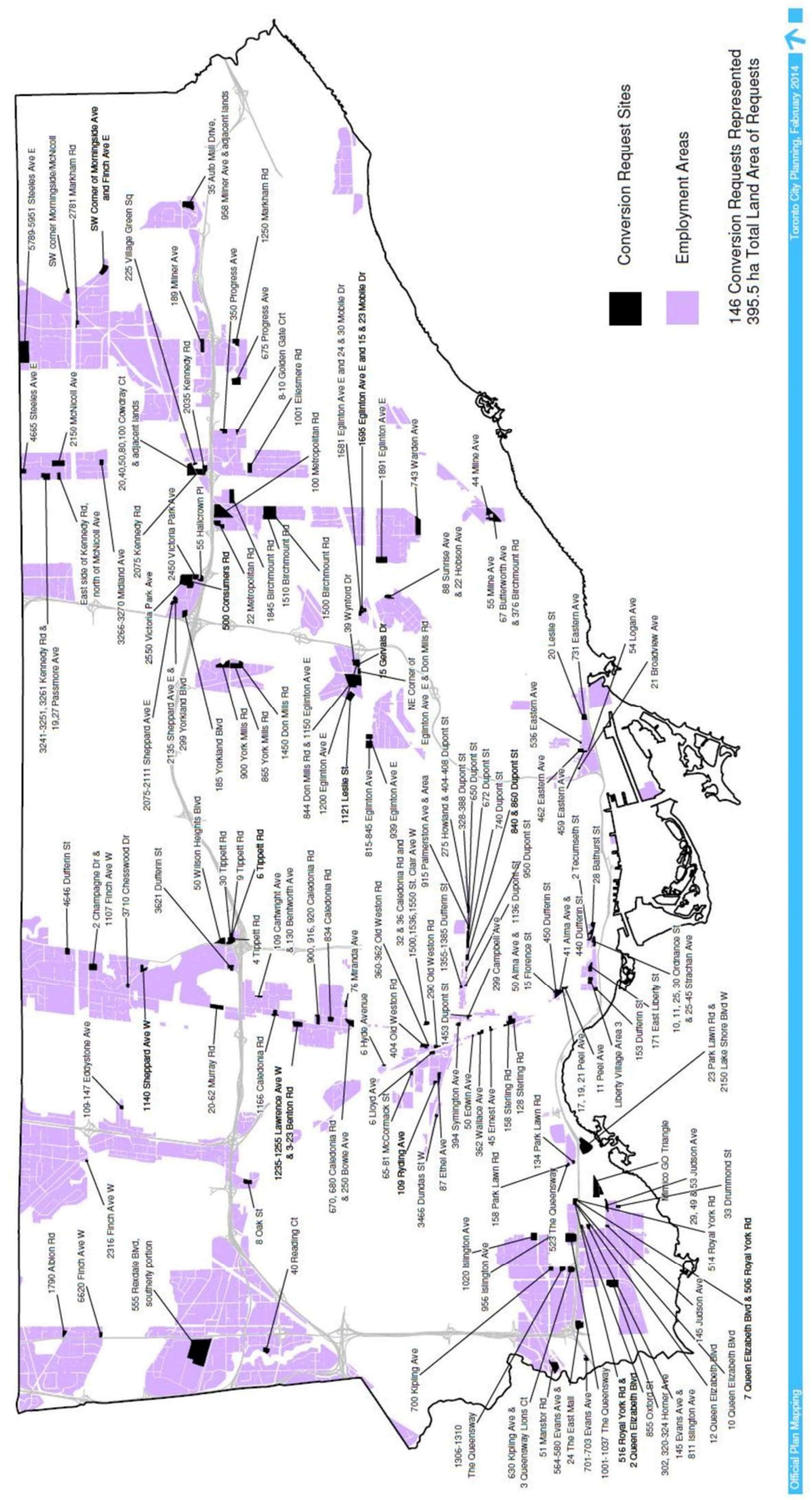

Figure 4 - Requests or Applications to Convert Employment Lands as of February 2014 


\section{Legal framework and the Market}

These documents provide not only the legal framework and policies by which land is regulated in the GTHA, but they also provide the definitions that each land use takes and the interactions with the Real Estate sector. It is therefore pertinent to analyze how these planning documents define Employment Areas and how they seek to regulate them.

A comprehensive review of these documents reveals that there is consensus in regard to the use of Employment Lands. The province of Ontario and the City of Toronto seem to be making efforts to protect them from market forces seeking to convert them for other more profitable purposes and they use tools at their disposal such as provincial and municipal documents to achieve that goal.

The Planning Act regulates the use of land and the procedures by which those uses can be changed (Ontario, 1956). Then we have the Provincial Policy Statements (PPS) which sets the province's vision on what the built environment should be (Ontario, 2014). All land use planning decisions, as per the Planning Act, must be consistent with the PPS (Ontario, 1956).

Starting with the PPS (2014), the document is clear with the purpose that employment areas should serve. According to it, Employment Areas are those designated by official planning documents destined to support activities of economic and business nature, namely, warehousing, manufacturing and other uses (Ontario, 2014). The previous definition is also highlighted in the Growth Plan for the Greater Golden Horseshoe (2006), which, as a document that provides guidelines of how and where the cities should grow, adds another level of detail about other concepts that should be read in conjunction with employment areas. First, Economic Employment districts are local areas identified by the Ministry of Infrastructure to protect them and be destined for employment uses. Additionally, Strategic Settlement Employment Areas are areas destined for employment uses that require large amounts of land and access to major highways for business to operate. Finally, the concept of Prime Employment Areas mimics the previous, but apart from being located close to a major corridor, they must also be located next to major distribution facilities (Ontario, 2006).

The Toronto Official Plan (2015) provides a definition for Employment Areas quite similar to those presented by the above mentioned documents, but it is more detailed in regard to the uses that are permitted within their boundaries, namely, "offices, manufacturing, warehousing, distribution, research and development facilities, utilities, media facilities, parks, hotels, retail outlets ancillary to the preceding uses, and restaurants and small scale stores and services that serve area businesses and workers" (City of Toronto, 2015). 
The City of Toronto's Zoning By-Law number 569-2013, does not provide a definition of Employment Areas per se, however it makes reference to it by indicating that uses within the Employment Industrial Zone category must satisfy the Employment Areas' definition set by the official plan (City of Toronto, 2016).

In line with the definitions provided, these planning documents provide guidelines on how to preserve employment areas and how to enhance them so they can serve present and future needs. The PPS, as a document that promotes complete communities through efficient land use, highlights the critical role that employment areas have in achieving the goal of a competitive city. It prescribes certain actions to promote economic development such as the provision of opportunities for a variety of economic sectors. In particular, the document recommends to ensure that there are sufficient employment lands for current and future needs, required infrastructure to support them and, protection against conversion of those lands that are close to major transport infrastructure. In regard to conversion of employment areas to non-employment uses, the document mandates that this can only be done after a "municipal comprehensive review" and after proving that the lands are not needed for employment purposes neither at the time of the request nor in the future (Ontario, 2014).

In parallel, The Growth Plan for the Greater Golden Horseshoe, a document conceived to be a framework for growth in the GGH, makes multiple reference to employment as being a critical element of Complete Communities to be successful. It is important to highlight that Complete Communities are places where people can work, live and play within a short travel distance through their entire lifetime. With that in mind, understanding that the nature of work in the GGH is progressively shifting from heavy industrial to knowledge-based jobs, this framework mandates to provide enough serviced land to suit a wide range of employments (Ontario, 2006).

A novelty in this document is the distinction between Prime Employment Areas and Employment Areas as classifications that will be given special attention in relation to adjacent land uses, urban fabric, and conversion to non-employment uses. In detail, Prime Employment Areas should not have adjacent land uses that are not related to the primary employment use, they should be planned with freight transport considerations in mind and its conversion to non-employment uses is prohibited. A slight difference is observed in Employment Areas where non employment uses are discouraged but can be integrated with the employment uses in place. Also, Employment Areas must be developed with transportation access infrastructure in mind and can be converted to nonemployment uses provided that a municipal comprehensive review is done (Ontario, 2006). An important element to note in this document is the approach that planning policy is taking towards public transit infrastructure to serve future employment areas.

As it would be expected from a municipal document, the City of Toronto's Official Plan is more detailed in relation to how it regulates Employment Areas and uses within them. It is consistent with the Growth Plan for the Greater 
Golden Horseshoe when it recommends that those uses should be accessible within employment areas. However, it is also prescriptive about uses that could impact the performance of these areas such as places of worship and post-secondary institutions (City of Toronto, 2015).

One of the features of the Official Plan is the development criteria for Employment Areas. It contains policies that seek to change the traditional image that Employment Areas have always displayed by providing for landscaping to create an attractive streetscape and buffering between these areas and residential areas. Also it calls for the creation of value added employment, promotion of active transportation and reduction of nuisances like odours, noise and vibration coming from activities typical of industrial zones (City of Toronto, 2015).

Toronto's Official Plan introduces the concept of Regeneration Areas, a new area that will later be referenced in a case study. Regeneration Areas are versatile in nature, they can host an array of uses and allows the re-purposing of underutilized or abandoned areas or buildings that are left in that state as a result of a changing industry and moving patterns (City of Toronto, 2015).

Some highlights regarding these criteria are the need of a secondary plan before any development takes place. The plan should include urban design guidelines consistent with the surrounding character, a community improvement strategy that considers streets, sidewalks and parks, and policies that take into consideration environmental and transportation improvements (City of Toronto, 2015).

\section{Economic Value of Employment Areas}

From a local perspective, a report prepared by the City of Toronto General Manager of the Economic Development and Culture department and the Chief Planner and Executive Director of the City Planning department (2013) provides a great understanding about the economic value of employment areas, which is based on jobs, economic output (gross domestic product), taxes, construction permits, employment diversity and physical space required (City of Toronto, 2013).

According to the report, in regard to economic output, employment lands generated $\$ 43$ billion or $28 \%$ of the city's total GDP for 2012. The authors of the report estimate that nearly $35 \%$ of the jobs and $40 \%$ of the GDP are a result of export activities occurring in employment lands. These jobs produce a trickledown effect that creates more jobs as a result of goods purchased by companies in charge of developing the exported products.

Additionally, workers in those jobs also generate further employment as they spend their income on goods and services (City of Toronto, 2013). According to a report prepared by Malone Given Parsons (2012); there are 
estimates that for each 1000 export based manufacturing jobs, 1200 indirect jobs are created in Ontario (Malone Given Parsons Ltd., 2012)

In terms of taxes, the City of Toronto Staff report (2013) indicates that Employment areas generate on average $12 \%$ of all property taxes in the City, representing $\$ 725$ million in property tax revenues. Further, the report indicates that in 2011, \$239.6 million were collected from industrial properties. The report argues that the funds collected from industrial and commercial properties represent more than the cost of the services provided by the municipality while residential properties generate more expenses than the amount of property taxes collected (City of Toronto, 2013).

In terms of jobs the same report indicates that employment lands contain about $25 \%$ of Toronto's jobs, this represents about 392,000 employees. Additionally, 36\% of all manufacturing jobs are located in these areas. One important argument drawn from these numbers is that jobs diversity is another of the many benefits of having a solid supply of employment lands because during economic downturns the impact of a recession would not affect every sector the same way and therefore the damage would be mitigated. This would translate into an example of a resilient economy (City of Toronto, 2013).

Another benefit identified by the report team in relation to employment areas is that, since they are located all over the city, people working near these areas could benefit from a shorter commute, which in turn translates into better quality of life (City of Toronto, 2013).

Finally, another economic value of employment lands is observed in the value of building permits issued in those areas between 2006 and 2010, which was calculated to be around \$2.8 billion. This gives another reference to the economic activity that employment lands generate (City of Toronto, 2013).

\section{Supply and Demand of Employment Lands}

In order to make a decision of retaining or converting an employment area, one of the first questions to be considered is whether there is enough supply of industrial and commercial areas to satisfy the current and future demand. In relation to this request, the City of Toronto hired Malone Given Parsons to prepare a report that, apart from providing policy recommendations to achieve the City's economic objectives, it also sheds light on the status of supply and demand of these areas. In detail, the report highlights that, from 1990 to 2011, the growth of office space has stagnated in the downtown, employment districts, areas and avenues. But most importantly, the land deficits projected for the City is an element of concern. (Malone Given Parsons Ltd., 2012). 


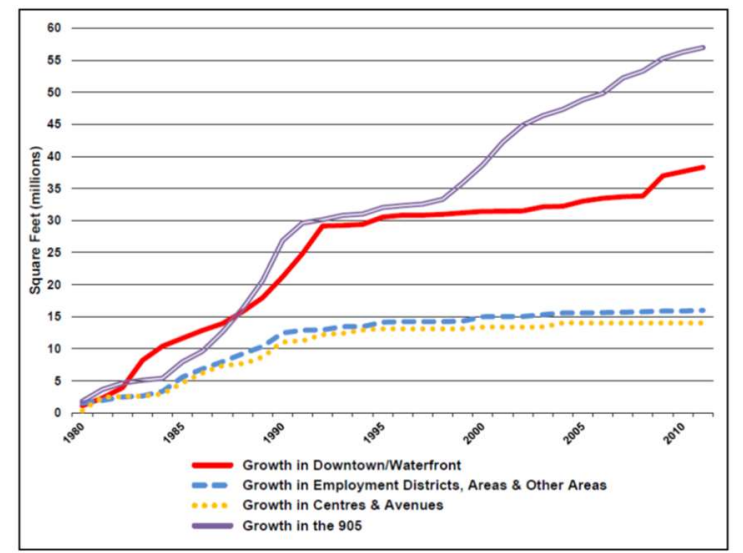

Figure 5 - Growth of Office Space - Toronto vs. the 905

Also, the report, based on population and jobs growth, provides high and low demand scenarios paired with a projection of land availability and demand by 2031 and 2041. It classifies lands by functionality types and potential uses as follows:

- Type A corresponds to Employment Districts and Employment Areas,

- Type B Downtown \& Central Waterfront, Centres, Business Parks

- Type C Avenues (+ Mixed Use Areas Outside of Avenues, and Other areas)

For Type A, our area of interest, the projected supply and demand table shows a deficit under a high demand scenario, which is based on numbers prepared by the Ontario Ministry of Finance. But more dramatic is the forecast for Types B and C functionalities, which show land deficit under both low and high scenarios (Malone Given Parsons Ltd., 2012). 


\begin{tabular}{|l|cc|ccc|}
\hline \multirow{2}{*}{$\begin{array}{l}\text { Land Needs vs. 'A' Lands Supply } \\
\text { (hectares) }\end{array}$} & \multicolumn{2}{|c|}{2031} & \multicolumn{2}{c|}{2041} \\
\cline { 2 - 6 } & Low & High & Low & High \\
\hline Supply & 686 & 686 & 686 & 686 \\
\hline Needs & & & & & \\
Industrial @ & $98 \%$ & 255 & 695 & 416 & 1,001 \\
Office @ & $3 \%$ & 1 & 2 & 1 & 3 \\
Retail \& Service @ & $35 \%$ & 102 & 151 & 133 & 224 \\
Institutional @ & $15 \%$ & 45 & 78 & 72 & 128 \\
\hline Total & & 403 & 926 & 622 & 1,356 \\
\hline Surplus/(Deficit) & 283 & $(240)$ & 64 & $(670)$ \\
\hline
\end{tabular}

\begin{tabular}{|l|ccc|cc|}
\hline \multirow{2}{*}{$\begin{array}{l}\text { Land Needs vs. 'B' Lands Supply } \\
\text { (hectares) }\end{array}$} & \multicolumn{2}{|c|}{2031} & \multicolumn{2}{c|}{2041} \\
\cline { 3 - 6 } & Low & High & Low & High \\
\hline Supply & 196 & 196 & 196 & 196 \\
\hline Needs & & & & & \\
Industrial @ & $2 \%$ & 5 & 14 & 8 & 20 \\
Office @ & $90 \%$ & 25 & 52 & 37 & 85 \\
Retail \& Service @ & $35 \%$ & 102 & 151 & 133 & 224 \\
Institutional @ & $30 \%$ & 90 & 156 & 144 & 255 \\
\hline Total & & 222 & 373 & 322 & 584 \\
\hline Surplus/(Deficit) & & $(26)$ & $(177)$ & $(126)$ & (388) \\
\hline
\end{tabular}

\begin{tabular}{|l|ccc|cc|}
\hline \multirow{2}{*}{$\begin{array}{l}\text { Land Needs vs. 'C' Lands Supply } \\
\text { (hectares) }\end{array}$} & \multicolumn{2}{|c|}{2031} & \multicolumn{2}{c|}{2041} \\
\cline { 2 - 6 } & Low & High & Low & High \\
\hline Supply & 69 & 69 & 69 & 69 \\
\hline Needs & $0 \%$ & 0 & 0 & 0 & 0 \\
Industrial @ & $7 \%$ & 2 & 4 & 3 & 7 \\
Office @ & $30 \%$ & 87 & 129 & 114 & 192 \\
Retail \& Service @ & $55 \%$ & 165 & 286 & 264 & 468 \\
Institutional @ & & 254 & 419 & 381 & 667 \\
\hline Total & & $(185)$ & $(350)$ & $(312)$ & (598) \\
\hline Surplus/(Deficit)
\end{tabular}

Table 2 - Land Needs and Supply by Functionality

As can be observed in the tables depicted above, preserving these lands is critical to ensure that future job growth would not be compromised by a lack of available office or industrial space. However, the picture is not so dire. As was previously highlighted in this section, the Regeneration Areas classification in the Toronto Official Plan, offers a way to provide for employment spaces that could fill the gaps and deficits in office space. Nevertheless, secondary plans necessary for the conversion to this category must be carefully analysed to avoid the creation of spaces that restrict growth or limit the adaptability of companies wishing to expand within the city. 


\section{Literature review}

\section{The Value of Employment Lands}

In order to critically assess the need of employment lands it is important to understand the value that they have to the surrounding community. Howland's work in Maryland finds that the industrial sector remains an important source of jobs in Prince George County; where 32\% of jobs were located in 2007 (Howland, 2010). Then she argues that industrial areas are important as places where government services locate much of their operations such as street cleaning, recycling and snowplowing. Next, she mentions that "back-office" activities are held in industrial areas (Howland, 2010. P.42). These activities relate to those uses like printing, high tech manufacturing and other uses that support other industries.

Similarly, Howland (2010) indicates that industrial areas are places that support people's daily lives, for example, they are home to repair shops, household repair and warehousing. She adds that due to the often lower cost of rental in these areas, incubators and start-ups also find affordable places to get their businesses moving, thus making these areas important to the economy of a city. Finally, she points at a very important element that make industrial areas and the employments they generate unique: the fact that industrial jobs employ people with little training and offers them competitive salaries (Howland, 2010).

From a fiscal impact perspective, industrial areas are seen as sources of revenue that provide fiscal balance to cities (City of Toronto, 2013). However, this assertion must be carefully made, because there seem to be different views about the impact that different sectors may have on economic development. Burchel and Listokin (1992) assert that negative fiscal impacts are caused by land uses that demand higher than average services from local governments while positive impact happens with land uses that demand lower than average services (Burchell \& Listokin, 1992). Wong (2004) defines tax capacity as the product between the tax base and the average tax rate. Through different computer modeling iterations, he finds that not every industrial development brings positive fiscal balance in cities. In fact, he finds that the service industry has a positive impact on tax capacity while manufacturing, agricultural and retail does not. Further, he warns about increasingly large concentrations of service businesses because they wouldn't necessarily bring increasing tax capacity (Wong , 2004).

Finally, Hirsch (1964) asserts that in order to maximize fiscal resources, cities must target industries that have the potential to bring the best salaries and the smallest numbers of employees but he makes that assertion with emphasis on costs to support schools. He later finds that fiscal impact is positively correlated with family income and negatively correlated with number of employees because these individuals could pay more taxes to maintain schools (Hirsch, 1964). 


\section{Decision Making Methods and criteria development}

The criteria to assist in the decision making of converting, keeping or having a mix of employment and residential uses in Employment Areas is viewed in this paper as an exercise of rational decision making. According to Edward Banfield (1959) a rational decision is taken through a four step process in which the first begins with the analysis of the situation, where the planner thinks about every possible way to reach the desired ends and the conditions or limitations faced. Second, the definition of the ends, where desired outcomes are listed and prioritized according to their level of importance. Third, the design of courses of action, where all the steps or "commitments" required to achieve the ends are established. Finally, the fourth step is the comparative evaluation of consequences where the outcomes of taking a course of action are evaluated in reference to the ends sought (Banfield, 1959) .

A review of papers related to conversion of industrial land uses, as well as ongoing applications, provide insights on typical considerations that stakeholders such as municipalities, communities and developers have when dealing with conversion proposals. For instance, in a letter related to a conversion application submitted by Mondelez to re-designate a lot from Employment Area to Regeneration Area, a notable case which will later be analyzed as a case study, the applicant's consultant highlights some benefits like bringing more jobs to the area and achieving intensification goals set up in planning documents such as the PPS (Smith, 2013). Interestingly, this intensification goal has been found by David Cogliano (2012) when he studied land conversion justifications in his Master Research Paper. He argues that many applicants use this argument "to capitalize in the location of their site" (Cogliano, 2012, p.24).

In the face of conversion pressures and the need of a rational approach to make decisions, it is relevant to come up with criteria that assist in taking good planning decisions. One source that provides good insight on criteria considered for the above mentioned purpose is an Industrial/Residential Viability Analysis developed by the Federation of Canadian Municipalities (2016). This document contains a list of 17 questions that must be asked when municipalities face the conversion of a site from industrial to residential. For example, one of the most important questions asks about the existence of a residential development in the adjacencies to the site analyzed (Federation of Canadian Municipalities, 2016. p.38). In addition to this source, the Centre for Urban Research and Land Development, in a paper analyzing the creation of the Warden Woods Community in a former industrial site, points to one criteria that drives the majority of the re-designation conversions: the need of housing for families settling in Toronto (Clayton, 2015). While this is a noble purpose to convert a former industrial area, there are other considerations that have to be put in place.

Considering the factors that bring companies into one area is an important step in the analysis needed to preserve them. Karakaya and Canel (1998) developed a comprehensive list of business location factors out of an extensive research of multiple academic papers and surveys performed to chief executive officers of 84 companies. 
(Karakaya \& Canel , 1998). The list in table 3 is classified according to each factor's level of importance given by its mean rating. The scale indicates that 0 would be equal to "not important", 1 equal to "important", 2 equal to very important and 3 equal to "extremely important". The highlighted factors considered are the 10 most important; however, through factor analysis they also found that there are 6 underlying factors that influence business location and gather the elements of Table 3.

\begin{tabular}{|c|c|}
\hline Business Location Variables & Mean Rating \\
\hline Availability of skilled labor & $1.94 *$ \\
\hline Transportation facilities & 1.84 \\
\hline State tax rate & 1.83 \\
\hline State regulatory environment & 1.83 \\
\hline Real estate tax & 1.80 \\
\hline Proximity to major highways/seaports & 1.79 \\
\hline Proximity to major US airports & 1.75 \\
\hline Cost of utilities & 1.60 \\
\hline Construction prices & 1.56 \\
\hline Availability of local airport & 1.54 \\
\hline Land prices & 1.50 \\
\hline Local investment incentives & 1.43 \\
\hline Availability of suppliers (e.g. vendors) & 1.34 \\
\hline Educational level of residents & 1.30 \\
\hline Availability of existing building(s) for business & 1.29 \\
\hline Cost of housing & 1.25 \\
\hline Availability of medical services & 1.23 \\
\hline Availability of colleges/universities & 1.19 \\
\hline Availability of capital financing & 1.17 \\
\hline Presence of competing business & 1.16 \\
\hline Availability of low cost labor & 1.12 \\
\hline Availability of industrially zoned land & 1.11 \\
\hline Availability of fresh water & 1.05 \\
\hline Presence of distributors & 0.89 \\
\hline Availability of recreational facilities & 0.88 \\
\hline Availability of industrial park(s) & 0.72 \\
\hline
\end{tabular}




\begin{tabular}{|l|c|}
\hline Availability of unskilled labor & 0.49 \\
\hline
\end{tabular}

Table 3 - Importance of factors in influencing business site selection decisions

According to Karakaya and Canel (1998) the six underlying factors, organized by level of importance are:

- Costs: this variable is composed by elements like construction prices, land price, cost of utilities, real estate tax and state tax rate.

- Quality of Life: this factor is composed by availability of colleges and universities, education of residents, availability of recreational facilities, cost of housing and availability of industrially zoned land.

- $\quad$ Accessibility: this is composed by proximity to major airports, highways and available local airports.

- $\quad$ Resources: this is made by availability of unskilled labor, fresh water, industrial park, low cost labor, local investment incentives and state regulatory environment.

- Business environment: this is composed by availability of suppliers, presence of competing businesses, availability of distributors, capital financing and transportation facilities.

- $\quad$ Availability of existing buildings: curiously this is one was listed as not a very important factor.

It is important to note that the importance of factors may differ in relevance according to the type of industry. For instance, the manufacturing industry may give more importance to local investment incentives than the consultant's industry. Although in general terms the rating of table 2 applies for the majority of industries, strategies must keep in mind how industries, whether manufacturing, banking, insurance, consultants or retail; may value each location factor.

In a similar vein, Porter (1995) examines strategies aimed to revitalize the inner city from an economic development perspective. First he highlights the importance of clustering as a way to improve the competitiveness of a location or city. He asserts that clusters spur the growth of new suppliers, related companies, training programs and educational institutions (Porter , 1995). Clustering is defined as the phenomenon by which different companies of the same industry come together within short distance from each other. Benefits from this practice are varied such as access to skilled workers, larger supply chains and information (Hindle , 2008). Glaeser (2007) also highlight benefits associated to cost savings in transportation of goods, people and ideas. He asserts that high wages and real estate prices are associated with the willingness of workers to pay to access those areas (Glaeser, 2007).

Porter (1995) also refers to advantages that make inner cities supportive to successful businesses and roles for the government to make the necessary changes for businesses to relocate in the cities. In relation to the advantages, he points to "strategic location" as one element that brings companies closer to central business districts, logistical infrastructure and clusters of similar companies. "local market demand" represents another advantage since it provides the market for local businesses products that could be adapted to local population needs and further, be 
later exported. "Integration with regional clusters" represents another advantage by enabling companies to provide services and supplies to customers within the cluster and also allows them to compete in related products and services. Finally, "human resources" such as eager low and high skilled workers spur further job creation once companies become successful and promote further business creation (Porter , 1995, pp. 57-59).

According to Porter (1995) governments should create the proper environment for businesses to develop instead of directly helping or funding them. To do this, he first proposes to identify what are the areas most likely to improve the economic viability of the city and channel the necessary funds to those areas. Further, he indicates that government should reduce bureaucracy costs and streamline procedures to increase the economic potential of the inner city. They should also approach the creation of infrastructure in a way that improves the movements of goods and people within the target areas. Finally, governments should bring economic development programs assisted by known private sector institutions and instead of providing subsidies directly to businesses they should use them in works that bring economic success such as better security and environmental cleanup (Porter , 1995).

Once understanding the importance of location factors in preserving industrial areas and considerations that must be taken into account to analyze conversion proposals, we must understand what drives conversions and how to proceed upon different scenarios. Lester, Kaza and Kirk (2013) argue that industrial land preservation policies should be tailored to each city's industrial trends and behaviours. Further, they point to five factors that determine the likelihood of an industrial site being converted to other uses.

- $\quad$ First, they have identified that parcels closer to central business districts are more likely to convert.

- Second, neighborhood real estate dynamics, in regard to price appreciation of properties, represents a good determinant of the probability of a parcel to change uses. Those parcels close to high valued areas are more likely to convert.

- $\quad$ Third, parcels associated with highly successful industries are less likely to convert since they can withhold larger rent prices.

- $\quad$ Fourth, location specific protection policies can greatly reduce the chance of a lot conversion.

- $\quad$ Finally, environmental hazards curiously were identified as non deterrent to conversion since this factor is associated to brownfield redevelopments. Parcels close to brownfields, in spite of the high costs of decontamination, are very likely to be converted (Lester, Kaza, \& Kirk, 2013).

Howland (2010) presents an approach that carefully looks and classifies industrial areas mainly in terms of level of demand, rate of vacancy and rent rates. From the study, it is interpreted that, in some cases, conversion would not affect employment or economic development in a city. The first category corresponds to areas that had no demand for industrial use. The second category grouped the areas that showed little demand for industrial uses. The third category considered areas with weak demand for industrial uses but good demand for office and retail 
uses. The fourth category groups areas with good industrial activity and demand but showing signs of other competing encroaching uses. And the fifth category corresponds to industrial areas that had excellent economic activity and maturely developed (Howland, 2010).

Her study conclusions reveal that in their study area, very few jobs would be lost if land in categories 1, 2 and 3 were rezoned and she argues that there would be no major issues if these lands are converted to other uses. However, for category 4 the situation is slightly more complex. In detail, category 4 was sub categorized in four more classes with different outcomes for each of them. First, whenever an industrial area showed healthy activity but had conflicts with non industrial uses she recommends to discourage land use speculation and encroaching uses by creating protections to the industrial character of the area through urban design, infrastructure investment and environmental laws (Howland, 2010).

Whenever healthy industrial activity coexisted with good commercial and office uses with little conflict, it is recommended that government needs no immediate action or intervention against development. However, where healthy industrial, office and retail uses locate next to highways and other important facilities it is recommended that more investment is put towards improving technology capabilities and facilitate the installation of light manufacturing and high quality office space through urban design and planning (Howland, 2010).

Finally, Howland (2010) recommends to let the market deal with situations where industrial uses have already lost their stand or are progressively being discouraged by other uses (Howland, 2010). Although her recommendations are very well substantiated, they miss considering other aspects like the impact of increased traffic and incompatible uses by emerging developments. 


\section{Methodology}

In order to fulfil the objectives of this research paper the first step was to identify the supply and demand situation of employment areas and what is the projected demand for these. These figures will help to understand how much conversion would be acceptable. A report prepared by Malone Given Parsons (2012), sheds light on these numbers (refer to figure 2).

Also, to obtain the order of magnitude of the potential loss of employment lands it is necessary to evaluate how much of them are under pressure for conversion. To get this number, the list of applications to re-designate employment areas within the last municipal comprehensive review of the official plan, contains the amount of land subject to conversion.

In order to understand the criteria that planners at the City of Toronto used to evaluate applications, a sample of 30 applications was extracted from the above mentioned document. The proponents applied to re-designate employment areas to other uses like "Regeneration Areas" or "Mixed Use". Each of the 30 cases were evaluated through content analysis to categorize the arguments that planners used when reviewing the applications. An effort was made to capture cases with different outcomes to capture a variety of arguments used to approve or refuse different requests.

According to Hsieh and Shannon (2005) Content analysis is a research method used to interpret written text by classifying it based on themes observed (Hsieh \& Shannon, 2005). According to the same source, there are three types of content analysis: conventional, directed and summative. For the purposes of this research, the directed approach was selected. Directed content analysis seeks to confirm an existing theory or framework of analysis that will later be used to study a case or phenomenon. For the purpose of this paper, existing theory is represented by supporting literature of other researchers of this topic, local and provincial planning document, and local policy strategies. For example, one of the theories is that the likelihood of a site converted to non employment uses depends on certain location factors (Howland, 2010). These findings were summarized and used as key phrases to establish comparison with similar summaries of the development submissions and employment preservation strategies. For example, one of the keywords that will be used to evaluate our data would be "Proximity to a Central Business District".

Hsieh and Shannon (2005) mention that this approach helps to confirm existing theories or elaborate on them, however they also warn about the approach limitations, listing bias as one of them. They assert that the approach leads more to confirm rather than to test the validity of theories. Further, they mention that researchers may omit contextual elements of the issue being studied (Hsieh \& Shannon , 2005). While these are valid arguments, given 
that the purpose of this paper is to create a guideline to evaluate applications and identify gaps, it is advisable that this is funded on existing academic literature to provide a solid and meaningful contribution to this area.

To illustrate the categorization process, a case from 145 Evans Avenue comes in hand. Inside the case, the "Planning Rationale" section depicts the arguments used by planners to support their decision to approve or refuse the request. For example, one of the arguments was that "The site is immediately adjacent to a residential neighbourhood with community infrastructure such as public schools, parks, community centres and libraries to accommodate the proposed residential conversion" (City of Toronto, 2014). In this case, the categorized argument is "Available community infrastructure".

To better understand how arguments would affect a decision of a re-designation, each one was also classified within the following categories:

- $\quad$ Criteria that would lead to a re-designation

- Criteria that would discourage re-designation

- Criteria that would lead to, or discourage a re-designation

In order to identify gaps and complement criteria used by planners, a literature review was performed. Authors like Green Leigh and Hoelzel (2012) were consulted to incorporate evaluation criteria such as the site's ability to provide services to the city or the site's proximity to an area where important research is happening. Further, an “Industrial/Residential viability analysis" prepared by the Federation of Canadian Municipalities (2016), contributed to the evaluation criteria.

After gathering all this information, a questionnaire was developed to evaluate applications on a case by case basis. The final decision of a conversion request is also supported by conclusions drawn by Howland (2010). For example, in cases where a site is surrounded by non industrial uses one recommendation could be to let the market address the outcome (Howland, 2010).

Finally, to test the applicability of the guideline, a case study analysis was performed. The former Mr. Christie's cookie factory in Etobicoke, served as a site where this questionnaire was implemented. This site presents itself as a challenging location due to an existing encroachment from residential uses and its proximity to transit infrastructure.

Case study analysis is useful whenever an issue has to be studied in its real life environment (Flyvbjerg, 2006). Further it enables the researcher to understand how and why a phenomenon happens, therefore allowing to recommend further courses of action or instruments like planning policies (Yin, 1981). 
This project has also faced limitations. The first is access to information related to development applications. Although the data set used for this paper is quite comprehensive for the intended purpose, more data would provide more robustness to the conclusions later drawn in the paper. Further, this data is not easy to find and it is presumed that more conversion applications have been submitted but are not available to be consulted online.

Another limitation is time to review each application and analyze them at a more detailed level. For instance, it would be interesting to understand the timeline for final resolution of these cases in order to provide the general public an idea of how long would similar cases take to be finalized.

Literature was also found to be limited in relation to factors that are considered in the analysis of these reconversions. Although planners at the City of Toronto seem to cover almost all aspect that academic literature has deemed as important, there may underlying gaps that for reasons of time and resources were not easy to be found. This issue could use more attention from the planning community.

Finally, another limitation of this guideline is that it depends on detailed information in order to provide an informed opinion. For example, the proposal's potential to maintain or create more employment uses depends on details of the development that may not be available at the initial stages of the conversion request. However, this is also a strength, since it allows to highlight missing pieces of information that are critical in the decision making process. 


\section{Analysis and results}

The report from Malone Given Parsons concludes that under favorable economic conditions there will be more of these lands needed in the future. They also argue that conversions from industrial usage to other uses should be discouraged if we want to prevent deindustrialization and loss of jobs (Malone Given Parsons Ltd., 2012).

From the list of applications of the last municipal comprehensive review of the City of Toronto Official Plan, it was noticed that requests to convert employment areas represented close to 400 hectares of land (City of Toronto, 2014). The supply seems to satisfy the need until the year 2031 under a low demand scenario but the needs under a high demand scenario are 926 hectares, leaving a 240 hectares' deficit (Malone Given Parsons Ltd., 2012).

Within the sample of 30 applications, 8 applications were approved for re-designation to mixed use, neighborhoods and other categories listed in the official plan, 14 applications were refused and required to remain under employment areas, and 8 applications resulted in a mixed decision where some areas of the proposed site were required to be kept as employment areas and other parts re-designated to categories like regeneration areas, mixed use or neighborhoods. (refer to table 4). From this list of applications compiled, it was observed that certain arguments led to re-designation, refusals or decisions to have a mix of employment areas and other uses. 


\section{Conversion Sites}

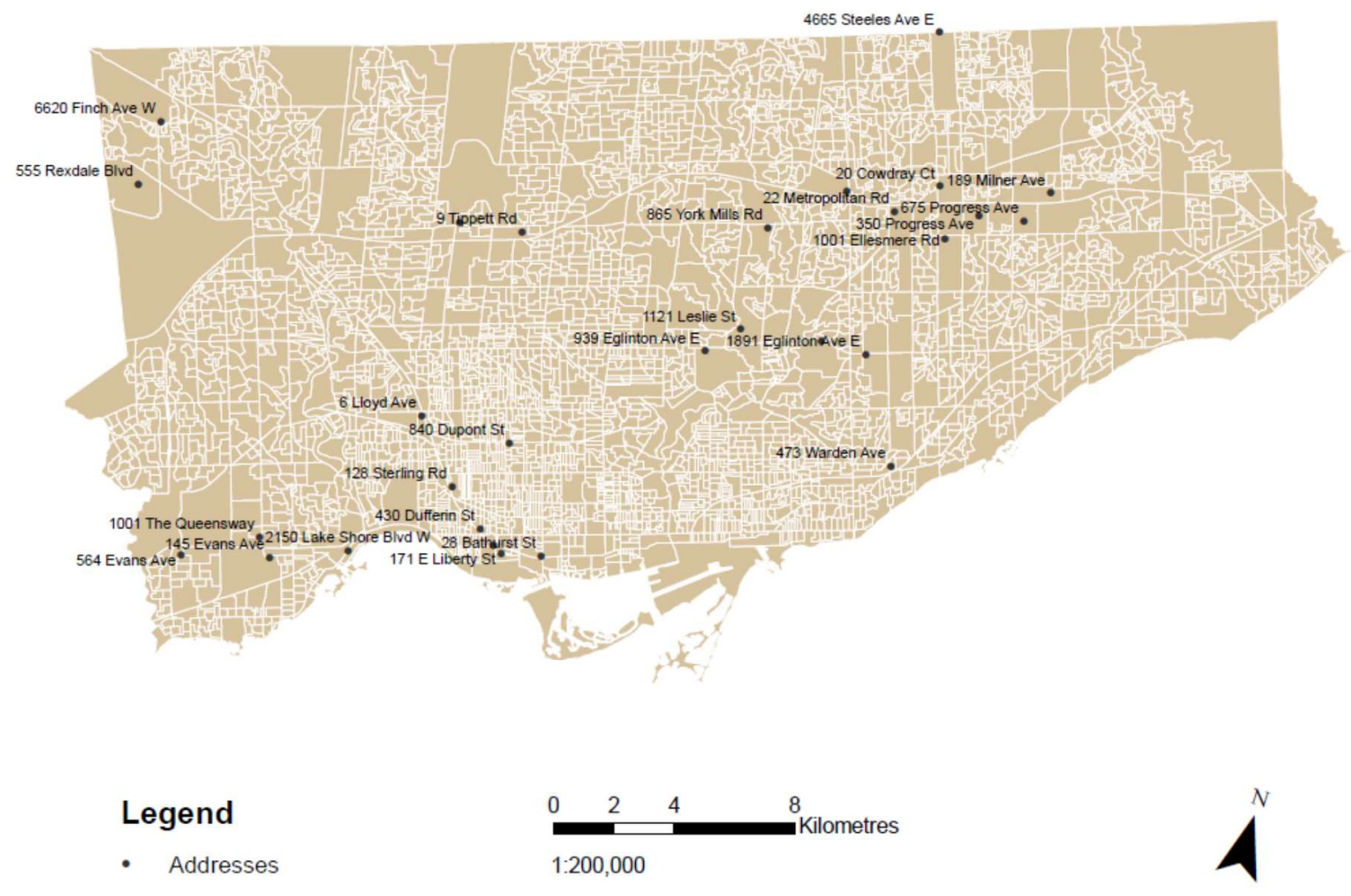

Figure 5 - Sites chosen for criteria analysis 


\begin{tabular}{|c|c|c|}
\hline Site & Proposed & Decision \\
\hline 20-62 Murray Road & $\begin{array}{l}\text { Re-designate from employment to } \\
\text { regeneration areas }\end{array}$ & $\begin{array}{l}\text { Council recommends re-designation only through the } \\
\text { creation of a site and area specific policy or secondary } \\
\text { plan. }\end{array}$ \\
\hline 9 Tippet Road & $\begin{array}{l}\text { Re-designate from employment areas to } \\
\text { mixed use areas }\end{array}$ & $\begin{array}{l}\text { Council recommends re-designation from employment } \\
\text { areas to Regeneration Areas }\end{array}$ \\
\hline $\begin{array}{l}1121 \text { Leslie Street north of } \\
\text { Eglinton Avenue East }\end{array}$ & $\begin{array}{l}\text { Convert employment lands to allow } \\
\text { three residential towers }\end{array}$ & Refused \\
\hline 6 Lloyd Ave & $\begin{array}{l}\text { Re-designate employment areas to } \\
\text { mixed use areas }\end{array}$ & $\begin{array}{l}\text { Approved Re-designate employment areas to mixed } \\
\text { use areas }(2 / 3) \text { and retain }(1 / 3) \text { as General } \\
\text { employment area }\end{array}$ \\
\hline 6620 Finch Avenue West & $\begin{array}{l}\text { Re-designate employment area to } \\
\text { mixed use }\end{array}$ & Refused \\
\hline 555 Rexdale Boulevard & $\begin{array}{l}\text { Re-designate employment area to } \\
\text { mixed use }\end{array}$ & Approved \\
\hline 865 York Mills Road & $\begin{array}{l}\text { Application to amend the official plan to } \\
\text { allow a mixed use development on } \\
\text { employment area }\end{array}$ & Refused \\
\hline 4665 Steeles & $\begin{array}{l}\text { Convert from Employment Areas to } \\
\text { Mixed use area }\end{array}$ & Refused \\
\hline 2450 Victoria Park Avenue & $\begin{array}{l}\text { Re-designate from Employment Areas } \\
\text { to Mixed use area }\end{array}$ & Approved \\
\hline $\begin{array}{l}20,40,50,80 \text { and } 100 \text { Cowdray } \\
\text { Court and lands between } 50 \text { and } \\
80 \text { Cowdray Court }\end{array}$ & $\begin{array}{l}\text { Re-designate from Employment Area to } \\
\text { Mixed use area }\end{array}$ & Approved \\
\hline 189 Milner Avenue & $\begin{array}{l}\text { Re-designate from Employment Areas } \\
\text { to Mixed Use Areas }\end{array}$ & Refused \\
\hline 350 progress avenue & $\begin{array}{l}\text { Re-designate from Employment Areas } \\
\text { to Mixed Use Areas }\end{array}$ & Refused \\
\hline 675 progress avenue & $\begin{array}{l}\text { Re-designate from Employment Areas } \\
\text { to Mixed Use Areas }\end{array}$ & Approved to re-designate to Mixed Use areas \\
\hline 1001 Ellesmere road & $\begin{array}{l}\text { Re-designate from Employment Areas } \\
\text { to Mixed Use Areas }\end{array}$ & $\begin{array}{l}\text { East half re-designated as employment and west } \\
\text { retained as employment areas }\end{array}$ \\
\hline 22 metropolitan road & $\begin{array}{l}\text { Re-designate from Employment Areas } \\
\text { to mixed use areas }\end{array}$ & Refused \\
\hline 44 Milne Avenue & $\begin{array}{l}\text { Re-designate from employment areas to } \\
\text { neighborhoods }\end{array}$ & Refused \\
\hline $\begin{array}{l}1695 \text { Eglinton Avenue East } \\
\text { and } 15 \text { and } 23 \text { Mobile Drive }\end{array}$ & $\begin{array}{l}\text { Re-designate from employment areas to } \\
\text { mixed use areas and general/retail } \\
\text { employment areas }\end{array}$ & Refused \\
\hline 1891 Eglinton Avenue E & $\begin{array}{l}\text { Re-designate from Employment area to } \\
\text { mixed use areas }\end{array}$ & $\begin{array}{l}\text { Re-designate part fronting Eglington avenue to Mixed } \\
\text { use areas and keep southern portion as General } \\
\text { employment areas }\end{array}$ \\
\hline 473 Warden Avenue & $\begin{array}{l}\text { Re-designate to mixed use areas and } \\
\text { neighborhoods }\end{array}$ & $\begin{array}{l}\text { Refused but later approved by Ontario Municipal } \\
\text { Board }\end{array}$ \\
\hline 939 Eglinton Avenue East & $\begin{array}{l}\text { Re-designate from employment areas to } \\
\text { mixed use areas }\end{array}$ & $\begin{array}{l}\text { Re-designate lands to Mixed Use Areas and retain the } \\
\text { southern portion }(50 \mathrm{~m}) \text { for General Employment Areas }\end{array}$ \\
\hline 840-860 Dupont St & $\begin{array}{l}\text { Re-designate from employment areas to } \\
\text { Mixed-use areas }\end{array}$ & $\begin{array}{l}\text { Retain some employment areas and re-designate as } \\
\text { general employment areas (within } 30 \mathrm{~m} \text { from rail } \\
\text { corridor) } \\
\text { Re-designate other areas as regeneration areas and } \\
\text { provide a secondary plan }\end{array}$ \\
\hline 128 Sterling road & $\begin{array}{l}\text { Re-designate from Employment area to } \\
\text { Mixed Use Areas }\end{array}$ & Refused \\
\hline $\begin{array}{l}\text { 430, 436, 440-444 Dufferin } \\
\text { Street and } 41 \text { Alma Avenue }\end{array}$ & $\begin{array}{l}\text { Re-designate from employment areas to } \\
\text { mixed use area }\end{array}$ & Refused \\
\hline 28 Bathurst St & $\begin{array}{l}\text { Re-designate lands from employment } \\
\text { areas to mixed use areas }\end{array}$ & Re-designate as Regeneration Areas \\
\hline Liberty Village Area 3 & $\begin{array}{l}\text { Re-designate from Employment areas to } \\
\text { Mixed use areas }\end{array}$ & Refused \\
\hline
\end{tabular}




\begin{tabular}{|l|l|l|}
\hline 171 East Liberty St & $\begin{array}{l}\text { Allow construction of residential } \\
\text { development in Employment areas }\end{array}$ & $\begin{array}{l}\text { Retain majority of the lands as Employment areas and } \\
\text { designate them as Core employment areas. The rest } \\
\text { will be designated Mixed use areas }\end{array}$ \\
\hline 564-580 Evans Avenue & $\begin{array}{l}\text { Request to convert lands from } \\
\text { Employment Areas to Mixed use areas }\end{array}$ & $\begin{array}{l}\text { OPA 231 re-designated the portion of 564-580 Evans } \\
\text { Avenue to Mixed use areas and the portion abutting 24 } \\
\text { the East Mall as Core Employment Areas }\end{array}$ \\
\hline 1001-1037 The Queensway & $\begin{array}{l}\text { Proposal to convert Employment area } \\
\text { and re-designate as mixed use area }\end{array}$ & Refused \\
\hline $\begin{array}{l}\text { Ave Evans Ave and 811 Islington } \\
\text { Re-designate from Employment areas to } \\
\text { Mixed Use Areas }\end{array}$ & $\begin{array}{l}\text { Retain 811 Islington avenue as Employment Areas and } \\
\text { designate them Core employment areas. Convert 145 } \\
\text { Evans Ave to Neighborhoods }\end{array}$ \\
\hline 23 Park Lawn & $\begin{array}{l}\text { Re-designate from employment areas to } \\
\text { regeneration areas }\end{array}$ & \begin{tabular}{l} 
Refused \\
\hline
\end{tabular}
\end{tabular}

Table 4 - Sites proposed for conversion

\section{Criteria that discourages re-designation from employment areas to other designations}

These arguments shown in table 5 were often used by planners whenever the proposed use was not in line with the strategy for employment areas preservation (Refer to table 5). The City of Toronto has identified that in order to ensure job growth and economical prosperity, preserving land for a wide variety of industries is paramount (City of Toronto, 2013).

From this initial list, there are a few elements that deserve attention. The first 9 arguments are related to the possibility of the proposal to encourage more conversions in the future and compromise the viability of the larger employment area, in fact, this argument is used repeatedly in all the applications that were not recommended by the City of Toronto. For example, in the conversion request of 1121 Leslie St, the City of Toronto planners noted that "the requested introduction of residential and sensitive non-residential uses on the site will adversely affect the overall viability of the larger Employment Area", "reduce the inventory of lands designated Employment Areas" and "create a precedent for further conversions for residential and sensitive non-residential uses" (City of Toronto, 2014). This reflect the concerns and the commitment to avoid the loss of further employment areas. It also recognizes the snowball effect that successful conversions may have on other employment sites.

Other criteria such as proximity to sources of nuisance and existence of environmental hazards were listed as reasons that would deter a conversion. For instance, in the case of 6 Lloyd Avenue, one of the reasons for refusing the application is the existence of emissions from a nearby rubber factory. In this case, approving residential uses introduces two issues. One is the health risk that it presents to future residents and the other is the potential pressures created by future residents on existing industries, which could possibly bring them to closure or increase their operation costs. While not every industrial activity produces the same type of nuisance and polluting activity, it is important to keep these areas flexible enough to accommodate a variety of uses. 
Some of these issues were noted in the literature consulted for this paper. Lester, Kaza and Kirk (2013) argued that sites located in areas with employment protection policies were less likely to convert (Lester, Kaza, \& Kirk, 2013). Also Howland (2010) recommends to discourage conversion of these lands whenever non industrial uses had potential to introduce conflict with healthy industrial activity (Howland, 2010). Finally, Karkaya and Canel (1998) noted that availability of industrial zoned land was an important factor considered by investors when evaluating cities to install their businesses (Karakaya \& Canel, 1998).

\section{Criteria that encourage a re-designation from employment areas to other designations}

These arguments were brought up in the planning analysis of sites that were proposed to be re-designated from employment areas to uses that allow residential or commercial developments (Refer to table 5). Such uses fall into categories like Mixed Use and Regeneration areas in the Official Plan.

Some important elements can be drawn from these criteria for approvals. First, we can observe that the employment preservation policies have relevance in these approvals. Very frequently, these developers were given permission to incorporate residential uses with the condition that employment uses were preserved or increased. Although not necessarily industrial, offices and retail space are also considered spaces where employments are created.

A notable example is found in 4665 Steeles Avenue. In this proposal the developer requested to convert the site to mixed use areas. The City of Toronto later approved their request to convert to Regeneration Areas because the proposal was perceived as non threatening to the larger employment area and because it had potential to intensify employment uses by increasing the office gross floor area. Similarly, at 9 Tippet Road, the proposal was approved to re-designate the site to Regeneration Areas provided that the owner presented a plan to increase the nonresidential gross floor area.

Some of these approvals were the result of a need to address issues of compatibility. In the case of 20-62 Murray $\mathrm{Rd}$, conversion was allowed so that a future development would be consistent with the adjacent residential uses. This is also highlighted by the Federation of Canadian Municipalities' guideline, where one criteria to support a conversion is the adjacency of the study site to a residential area or having residential uses within $0.8 \mathrm{Km}$ (Federation of Canadian Municipalities, 2016). Lester, Kaza and Kirk (2013) also indicate that sites that are close to high valued areas, such as residential, are likely to be converted (Lester, Kaza, \& Kirk, 2013). Finally, Howland (2010) proposes that in cases where residential uses encroach poor performing industrial sites, the site should be re-converted. In summary, it is noted that existent, or recently completed, residential developments that are close to the area of study may influence the decision of approving a mixed use development proposal. 
Criteria that could lead to, or discourage conversion from employment areas to other designation

These arguments are quite important in the analysis of a re-designation proposal (refer to table 5). Indeed, they could dramatically influence the decision to convert or retain the employment uses of a proposed site. In some cases, the City of Toronto approved mixed use proposals after observing that they could act as buffers or separation to established neighborhoods from more employment intensive uses in their adjacencies. This is evidenced in the proposal for 145 Evans Avenue where city staff recommended low rise residential buildings to act as buffers to employment uses fronting Islington Avenue. In other cases, buffering was required as a condition in order to protect future residents from nuisances coming from adjacent more intensive uses. Also, 28 Bathurst Street is one example where city staff required the developer to provide a 70 metres buffer zone West of the development to protect the future residents from nuisances originating from a former meat processing centre, which is now closed. However, in 1121 Leslie Street, the proposal was refused for not having enough separation from adjacent employment uses.

Other elements may play their part in approving a proposal. In the case of 473 Warden Avenue, although there was a recognition that re-designating this site would compromise the ability to serve future employment uses, a decayed industrial activity on the area together with good access to transit led to a decision to allow non employment uses in the site. However, in cases like 1001-1037 The Queensway, the proximity to transport infrastructure and site visibility to potential employment uses, got in the way for developers in trying to convert this site to mixed use areas. In fact, authors like Karkaya and Canel (1998), Howland (2010) and Porter (1995) highlight proximity to transport infrastructure as a good asset to maintain for further development of employment areas.

\section{Gaps in the criteria}

The extracted criteria serve as a set of elements to be considered by planners and citizens involved in the decision process. However, further consultation from the author's research shows that there are a few gaps in the review process. For instance, it is pertinent to ask if the site could be redeveloped into uses that serve better purposes for the inner city? Possible uses could be warehousing or storage of city use equipment. Further, it would be relevant to ask if elements of the proposal consider revitalizing the industrial area (Green Leigh \& Hoelzel, 2012).

Also, another question that is pertinent to ask is whether the site is close to an area where important research activity is happening. This is relevant because the knowledge spillovers generated in clusters of small companies 
play an important role in the development and competitiveness of a city and should be a motive to discourage the conversion of a site to other non industrial or employment uses. (Lester, Kaza, \& Kirk, 2013).

Proximity of the site to a central business district is also another element that should be considered to deter a conversion request. Lester, Kaza and Kirk (2013) identify distance of a site from the central business district a key driver to conversion indicating that a site close to a CBD is more likely to convert due to their attractiveness for other purposes like retail and residential (Lester, Kaza, \& Kirk, 2013).

Another question that is pertinent to ask when evaluating a conversion is if the site has enough infrastructure to support industrial uses and what would be the cost of utilities compared to other cities or areas (Karakaya \& Canel ,1998). According to Blair and Premus (1987), state and local physical infrastructure is a location factor that is important for companies willing to install their operations in a city (John P. \& Premus, 1987). Indeed, the availability of telecommunications, roads, electricity and water, up to the levels required by an industrial park must be up to date or sizeable according to requirements of modern industry. This is particularly important in sites that have been abandoned, vacant or underutilized for decades. Additionally, ensuring that infrastructure capacity exist to support growth forecast is one of the policies listed in the City of Toronto's strategic plan for job growth (2013) (City of Toronto, 2013). Finally, the cost of utilities could make the difference between a feasible operation or a non profitable one.

Availability of existing buildings is another consideration that, while not as important, was listed as an underlying factor by Karkaya and Canel (1998) and also by Harrington and Warf (1995). Having a suitable building on a site may influence the costs of locating when having to remodel it or adapt it to a desired usage (Harrington \& Warf, 1995). The configuration and physical characteristics of the existing building could also mean that it can be redeveloped to accommodate tenants of different types of industry. However, this must not be done without appropriate guidelines of sustainable buildings so that compatibility with surrounding properties can be enhanced (Green Leigh \& Hoelzel, 2012).

Finally, another element that needs assessment is whether interest by industrial or commercial development has been shown for this site. It is important to highlight that this question lines up with policies of the City of Toronto strategic plan for accelerating job growth. In fact, policies $C$ and $D$ aim to support medium size enterprises, attract companies and investment and increase the support to high-value sectors and manufacturing companies (City of Toronto, 2013). 
In summary, the following questions, identified as gaps, were incorporated to a questionnaire that could be used as a guideline to assess cases where conversion from employment areas to other uses is proposed (refer to appendix B).

1. Does the proposal consider uses that provide services to the city? (snow removal, garbage collection)

2. Is the site close to an area where important research is being done?

3. Is the site in proximity to a central business district?

4. Is the site infrastructure capable to support the proposed development?

5. Are there buildings in the site that could be re-used or refurbished?

6. Is there any interest in the site by industrial or commercial businesses?

\begin{tabular}{|c|c|c|}
\hline Criteria & Used by City & $\begin{array}{l}\text { Not used by the } \\
\text { City (Gap) }\end{array}$ \\
\hline \multicolumn{3}{|l|}{ Criteria that discourages re-designation from employment to other uses } \\
\hline Proposal may encourage more conversions in the future & $\mathrm{x}$ & \\
\hline Proposal affects viability of larger employment areas & $\mathrm{x}$ & \\
\hline Site is part of a large employment area & $\mathrm{x}$ & \\
\hline Proposal in one of the few employment ready areas & $\mathrm{x}$ & \\
\hline Proposal is within an employment area or within an employment district & $\mathrm{x}$ & \\
\hline Site is adjacent to other employment or industrial uses & $\mathrm{x}$ & \\
\hline Proposal does not conform with employment land preservation policies & $\mathrm{x}$ & \\
\hline Proposal affects a pocket of employment lands and jobs within the area & $\mathrm{X}$ & \\
\hline $\begin{array}{l}\text { Proposal is not consistent with adjacent uses (example: a residential proposal within industrial } \\
\text { areas) }\end{array}$ & $\mathrm{x}$ & \\
\hline Lack of need to convert more employment areas to meet population growth targets & $\mathrm{X}$ & \\
\hline A portion of the proposal occurs on a flood plain & $\mathrm{x}$ & \\
\hline Start ups find the area affordable & $\mathrm{x}$ & \\
\hline Proximity to areas that could cause nuisance such as highways and manufacturing plants & $\mathrm{x}$ & \\
\hline Non industrial uses exposes users to risk such as accidents from truck traffic & $\mathrm{x}$ & \\
\hline Environmental hazard in the proposal's area & $\mathrm{x}$ & \\
\hline Block design and orientation not consistent with requirements & $\mathrm{x}$ & \\
\hline Excessive traffic may be generated & $\mathrm{x}$ & \\
\hline \multicolumn{3}{|l|}{ Criteria that encourages re-designation from employment to other uses } \\
\hline Proposal maintains employment uses & $\mathrm{x}$ & \\
\hline Proposal increases non residential area to add employment uses (commercial, industrial) & $\mathrm{x}$ & \\
\hline Proposal reduces potential manufacturing jobs but preserves or increases other types & $\mathrm{X}$ & \\
\hline $\begin{array}{l}\text { Proposal discourages large retail stores and promotes creation of restaurants, recreation and } \\
\text { entertainment facilities }\end{array}$ & $\mathrm{x}$ & \\
\hline Proximity to residential areas & $\mathrm{X}$ & \\
\hline Area never had traditional industrial uses & $\mathrm{x}$ & \\
\hline Similar residential developments approved in the past & $\mathrm{x}$ & \\
\hline Residential development already occurring in the area & $\mathrm{X}$ & \\
\hline Proposal area is isolated from larger employment area & $\mathrm{X}$ & \\
\hline Adjacent areas with secondary policies providing for residential uses & $\mathrm{x}$ & \\
\hline Development proposal complies with secondary plans and design guidelines & $\mathrm{x}$ & \\
\hline Development proposal plays important cultural role for neighborhood & $\mathrm{x}$ & \\
\hline Proposal includes affordable housing and mix of other housing forms & $\mathrm{X}$ & \\
\hline Proposal improves streetscape and public realm & $\mathrm{x}$ & \\
\hline \multicolumn{3}{|l|}{ Criteria where more information would be needed to make a decision } \\
\hline Compliance with local and provincial planning documents (Planning act, PPS, Official Plan) & $\mathrm{X}$ & \\
\hline Cross jurisdictional issues & $\mathrm{X}$ & \\
\hline Buffering from industrial areas or nuisance generating areas & $\mathrm{X}$ & \\
\hline $\begin{array}{l}\text { Density, built form, massing, height, shadows and design (in line or not in line with planning } \\
\text { regulations) }\end{array}$ & $\mathrm{x}$ & \\
\hline Proposal's influence on employment growth forecast & $\mathrm{x}$ & \\
\hline Attractiveness of proposed area for employment uses & $\mathrm{X}$ & \\
\hline
\end{tabular}




\begin{tabular}{|l|l|l|}
\hline Site visibility from road way & $\mathrm{X}$ & \\
\hline Compatibility with adjacent uses & $\mathrm{X}$ & \\
\hline Compliance with noise, emissions, odours and vibration standards & $\mathrm{X}$ & \\
\hline Relationship with adjacent community & $\mathrm{X}$ & \\
\hline Impacts on adjacent heritage properties & $\mathrm{X}$ & \\
\hline Available community infrastructure & $\mathrm{X}$ & \\
\hline Site adjacency to major transportation routes (highways, rail, airports) & $\mathrm{X}$ & \\
\hline Proposal's coverage by transit & $\mathrm{X}$ & \\
\hline Status of access roads & $\mathrm{X}$ & \\
\hline Parkland dedication & $\mathrm{X}$ & \\
\hline Sequence of construction in mixed use developments (Non residential first) & $\mathrm{X}$ & \\
\hline Compliance with infill good practices & & \\
\hline Proposal consider uses that provide services to the city & $\mathrm{X}$ \\
\hline Site is close to an area where important research is being done & $\mathrm{X}$ \\
\hline Site is in proximity to a central business district & $\mathrm{X}$ \\
\hline Site infrastructure is capable to support the proposed development & $\mathrm{X}$ \\
\hline Buildings on the site could be re-used or refurbished & $\mathrm{X}$ \\
\hline Interest in the site by industrial or commercial businesses & $\mathrm{X}$ \\
\hline Proposal considers revitalizing the industrial area & & \\
\hline Site is encroached by other residential uses & & \\
\hline
\end{tabular}

Table 5 - Criteria to evaluate re-designations 


\section{Case study}

\section{Site: Mr. Christie's Cookie Factory. South Etobicoke.}

To test the applicability of the guideline, Mr. Christie's former cookie factory has been chosen as a site. The intention is that, by going through questions of the guideline, the reader can reach a good planning decision.

The property is a polygonal parcel of approximately 11 Hectares. This is currently occupied by an industrial decommissioned building of 58,062 $\mathrm{m} 2$ where industrial operations of a former food company were held.

According to Zoning By-Law 304-30 through 304-33 the site is zoned Employment Areas (I.C1 - Industrial Class 1). It is bounded to the North by the Gardiner Expressway, the Canadian National Railway Lines and Employment Industrial Areas occupied by the Ontario Food Terminal Board (City of Toronto, 2000).

To the south, is bounded by one Bank of Montreal branch, the Humber Bay Park and mixed use developments comprising high rise residential and commercial properties. These areas are mixed use areas zoned as $\mathrm{CL}-\mathrm{H}-$ Limited Commercial Zone (Hold), R4 - Fourth Density Residential Zone and MU-H - Mixed Use (Hold).

To the east, the site is bounded by mixed use high rise residential buildings on Lake Shore Boulevard West. This is a mixed use area zoned as MU - Mixed Use, OS - Open Space, R4 - Fourth Density Residential Zone.

And, to the west, the site is bounded by Park Lawn Road and developments comprised of residential and commercial buildings. This is a Mixed Use Area zoned as CL-H - Limited Commercial Zone (Hold) and MU-H Mixed Use (Hold), R6 - Sixth Density Residential Zone, OS - Open Space

An amendment to the Toronto Official Plan has come into effect on December 2013. Employment Areas (formerly known as Employment Districts) have been divided into Core Employment Areas and General Employment Areas. Our area of interest falls under Core Employment Areas. Core Employment areas are exclusively dedicated to business and economic activities. More specifically, some of the permitted uses are manufacturing, warehousing, transportation facilities and vertical agriculture among others. Other uses that support the primary uses could be hotels and small scale restaurants (City of Toronto, 2015).

An application to modify the Official Plan and re-designate these lands from Employment Areas to Regeneration Areas has been submitted by Mondelez Canada, the site owners. Regeneration Areas allow for a mix of commercial, residential, light industrial, parks, open space, institutional and utility uses. Up to this date, no final decision has been made and the areas remain designated as Core Employment Areas. 
Secondary plans do not affect this lot, however, Site Specific Policy 15, which is applicable to this site, was amended and makes clear that any development proposal must be considered though a comprehensive plan that responds to Employment Areas policies.

Areas to the east of this site are being developed under the guidance of a secondary plan for a waterfront area (Appendix 4 - Secondary Plan). In parallel areas to the west are designated Mixed Use Areas and are under development.

In section 1.3.2.1, the Provincial Policy Statement makes reference to Employment Areas. It is important to note that this instrument seeks to protect these areas so they can be used in the future for this purpose (Ontario, 2014).

Further, in line with Official Plan Amendment 231 to the Official Plan, section 1.3.2.2 indicates that it only allows conversion to other uses by a comprehensive review of the plan if it is demonstrated that the land is not required for employment purposes (City of Toronto, 2015). This conversion element is reinforced in the Growth Plan for the Greater Golden Horseshoe (2006). Section 2.2.6 subsection 5 indicates that municipalities can only convert these areas to non employment uses by a municipal comprehensive review (Ontario, 2006).

The parcel is also adjacent to a higher order transit corridor, specifically a surface transit priority corridor (City of Toronto, 2015).

According to Pagliaro (2012), the site (which operated since 1948) used to be a cookie factory owned by Mondelez Canada after a splitting with Kraft Foods several years ago. It was the home of nearly 550 employees who lost their jobs after the factory closed in 2013 (Pagliaro, 2012). The reasons for closing are speculated but possible causes are better returns of the land obtained from a potential residential development, and issues of deindustrialization.

In relation to deindustrialization, Howland (2010) mentions that decentralization of manufacturing, lower wages in other locations, telecommunication improvements, falling transportation costs and rising values of land have led to lack of interest in the manufacturing industry (Howland, 2010).

The owner of this site has filed an application to re-designate the lands from Employment Areas to Regeneration areas with the intention to allow residential uses in these premises. Their most important arguments in support of this request are that obtaining such new designation could enable potential to generate more employment than what the site previously had. Also, it could promote residential intensification and a creation of a transit oriented development (Smith, 2013). 
However, The City of Toronto insists on retaining this site for employment uses and proposes re-designating it as Core Employment Areas on the basis of many valid arguments such as avoiding conversion to prevent other properties doing the same, compliance with employment land preservation of official planning documents, proximity to transport infrastructure and a potential reduction of employment lands inventory (City of Toronto, 2014).

\section{Case Study Discussion}

In order to test the relevance and effectiveness of the guideline developed in this paper, it seems pertinent to use the criteria to evaluate this application and later attempt to reach a concluding recommendation in regard to what could be a good planning decision.

It is important to begin by reminding that planning regulation in the province of Ontario and the City of Toronto mandates to preserve and protect employment lands for current and future needs (Ontario, 2014). This is a starting point that should be taken into account before getting involved in these discussions.

The site is in proximity to the Gardiner Expressway which is an important source of nuisance that generates noise and air pollution. Additionally, it is less than $100 \mathrm{~m}$ away from an important railway, a source of vibrations, noise and emissions. In addition to this, there is no separation or buffering from these areas, which would be an important requirement for incorporating residential uses.

The last preliminary report from March 2014, required an environmental impact study and a Contamination Site Assessment to determine if the site is exposed to contamination or has a source of environmental hazard that would make the site unsuitable for a mixed use development (City Planning, 2014). Mitigation or remediation measures would have to be submitted to address environmental hazards or any non compliance with existent noise or vibrations. In terms of natural hazards, the site is not located on a flood plain.

Regarding employment land preservation policies, the intention of the owner is to convert the site to Regeneration Areas, which do offer an opportunity to generate employment. However, after a revision of all the available case study documentation, the owners have not submitted details or concepts about the proposed development that allows judging the type of business targeted and the quantity of employments to be generated. As it is known, the Provincial Policy Statement and the Growth Plan for the Greater Golden Horseshoe require that decisions should be consistent and not conflicting with these two documents that seek to preserve employment areas for current and future needs. 
The site is not surrounded by other employment uses. In fact, it is surrounded by mixed use areas. However, a few hundred meters north of the site, the Ontario Food Terminal represents a good source of employments and a highly important link in Toronto's supply chain.

The area used to be a larger employment area but it has been progressively transforming into a mixed use area. In detail, this site falls into the Core Employment Areas category and is subject to Site Specific Policy Area \#15. It is noted that the proposal may affect a pocket of employment lands and jobs within the area because it proposes to convert the site into a designation that, while still allowing employment areas introduces other uses like residential.

The area had traditional industrial usage, it held the operations of the Mr. Christie's cookie factory. Further, it is in proximity to transit infrastructure and close to the city downtown area, which makes it attractive for employment uses. The site is also visible from the road, it faces Park Lawn Road and Lake Shore boulevard West.

In relation to a need of converting these lands to meet population growth targets, it has been determined by city planning that there is no such need in this case. It is important to highlight that this proposal could encourage more conversions in the future because it would set a precedent for other developers to capitalize on an increased value of land as a result of more demand and a sustained deindustrialization.

Although a traffic impact assessment would provide more details, preliminary observations show that potential non industrial uses in this site would not introduce risk from truck traffic. The majority of the traffic from the Ontario Food Terminal passes through exits of the Gardiner Expressway and sections of Park Lawn Road north of the site in discussion.

In regard to residential uses, according to Map 35 of the Toronto Official Plan, this site is adjacent to residential uses that are subject to Secondary Plan areas numbers 11(Motel Strip) and 35(Mimico-by-The-Lake). The later is still pending to be approved by the Ontario Municipal Board, but site observations show an encroachment of the area by existent and ongoing residential uses. 

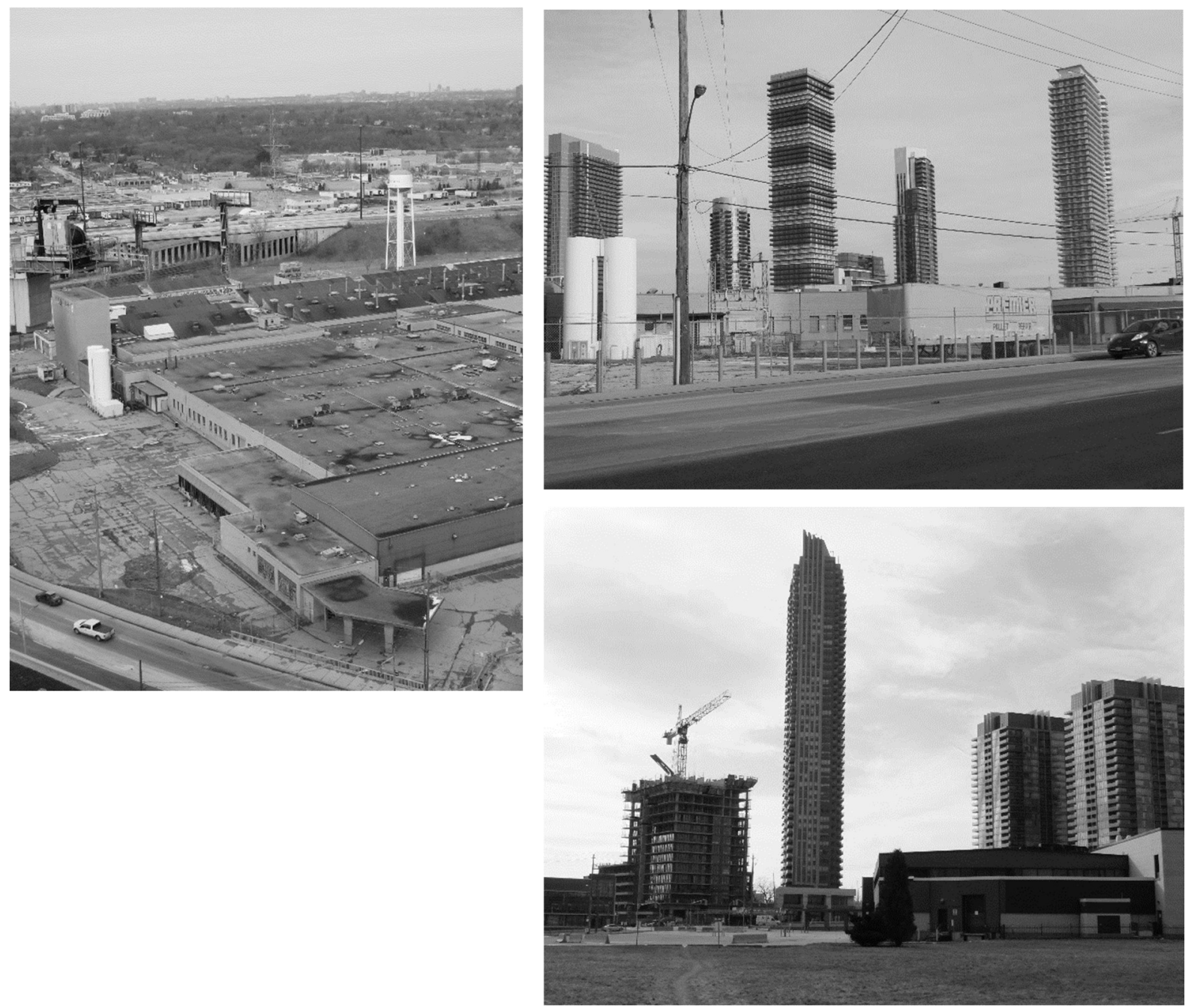

Figure 6 - Mr. Christie's Site (Aerial, South and West views)

According to meeting records compiled for this case study, the relationship of this site with the adjacent community is loaded with concerns. The most important ones highlighted are the refusal of more condos by existing resident since there is a perception that the area is exploding in population. Further, it has been highlighted that the area previously experienced frequent power outages and that further infrastructure improvements would be needed if more development will be brought into this site (City Of Toronto, 2013).

In terms of locational factors, the site is not isolated from a larger employment area. As it was mentioned before, the Ontario Food Terminal is located to the north of the site. Additionally, development is indeed occurring in the area. The site is actually encroached by existing and ongoing residential uses that have been previously approved. 
Retail stores should be consistent with the density and built form of the surrounding areas (J.C. Williams Group Limited, 2014). A preliminary report from City Planning (2014) indicates that the owner has requested that the Site and Area Specific Policy number 15 recognizes a long term redevelopment of the area and considers the usage of vacant portions of the area for large format retail (City Planning, 2014). This would be detrimental to the area and not in line with good planning.

Community infrastructure is critical to support residential developments in an area. According to documents from the last municipal comprehensive review of the Official Plan, this site has adjacent community infrastructure such as libraries, schools and community centres to support a potential residential development (City of Toronto, 2014). Further, the site is adjacent to major transportation routes such as the Gardiner Expressway and the CN Rails. Major transportation infrastructure is also available providing bus, street car and Go Train services to residents of the area. Finally, the Humber Bay Park is located south of the proposed site.

Toronto is a city where important research is happening. This site is a few kilometres away from the city central business district, universities and major hospitals that are at the forefront of cutting edge research. Having sites available to receive companies that contribute to this environment is critical and, according to Lester, Kaza and Kirk (2013), re-designation to non industrial or non employment uses should be discouraged (Lester, Kaza, \& Kirk, 2013).

The latest discussions with different stakeholders reveal that more infrastructure is needed to support potential businesses related to Information Technology and Data management. Further, the stakeholders report issues with hydro and water servicing (City of Toronto, 2013).

Finally, in relation to buildings that could be reutilized, the former cookie factory's buildings could be re-adapted to host a variety of services, nevertheless, further analysis must be done to understand the economic feasibility of this.

There are many aspects from the guideline that remained to be answered in this case study. This represents one of the limitations of this method. For example, regarding the proposal's influence on employment job growth forecasts, at this moment there are no details about the type of development that will occupy the site; therefore, it is not possible to determine whether it will influence employment or not. In fact, the possibility to reduce manufacturing jobs and preserve or increase other types of employment, could change if the proposal considers other uses like offices or light manufacturing.

Missing information is also needed to answer the following questions: 
- Proposal consistency with adjacent uses

- Affordability of the employment area for small or new starting companies

- Amount of traffic generated by the proposal

- Proposal compliance with secondary plans and design guidelines

- Proposal's mix of housing form

- Proposal's compliance with requirement of block design, orientation, density, built form massing, height, shadow and design

- Proposal's potential to create restaurants, recreation and entertainment facilities

- Proposal's cultural role in the neighborhood

- Inclusion of affordable housing

- Potential to improve streetscape and public realm

- Compliance with local and provincial planning documents

- Cross jurisdictional issues

- Impact on adjacent heritage properties

- Sequence of building (non residential buildings must be completed first)

- Uses that provide services to the city (snow removal, garbage collection, among others)

- Interest of businesses in the site

In spite of this missing information, the guideline still represents a useful instrument to make a decision of converting or retaining the employment uses of the site studied. In fact, if solely the arguments of planners at City of Toronto would be used, the conversion of this site would be discouraged. However, one of the considerations of this guideline is if there are other residential developments occurring in the area. This last item is important because it is an indication of encroachment of an employment area by residential uses. In this case, Howland (2010) would recommend to let the market follow its course, which would translate into letting the area be converted to a Mixed Use designation.

Indeed, the guideline allows to conclude that this site could be re-designated as Mixed Use or Regeneration Areas. For instance, a mixed use site could also allow employment uses, especially in the new knowledge economy where large spaces are not needed. However, similar cases have shown that there could be a section of this site dedicated for industrial use and another for mixed use. In fact, some industrial uses could be consistent with the surrounding area and not necessarily generate conflict. For instance, Redpath Sugar has proven the point that it is possible to coexist with adjacent residential uses.

Although introducing residential uses would bring the potential for increased traffic, it is also true that the area is well served by three different transit systems: Bus, Street Car and Go Train. 


\section{Conclusion and recommendations}

This research led to a guideline that drew, from different sources, the factors that are important to make decisions of approving or refusing a request for employment lands conversion. Elements that encourage and discourage these conversions were identified as well as other elements that needed further analysis to reach a decision. It also drew from elements of the City of Toronto strategic plan in order to be coherent with employment preservation and creation policies. Additionally, gaps such as proximity of sites to central business districts and availability of reusable buildings were identified and incorporated to the guideline. Finally, by applying the guideline to a case study it was demonstrated that different outcomes, like the approval of a conversion proposal, could be attained and in some cases be considered as a good planning decision.

Additionally, the research identifies that there are certain limitations that must be addressed to ensure effectiveness. For instance, lack of information in a proposal may leave some of the guideline's questions unanswered and therefore pose difficulties to the decision making process. Therefore, stakeholders must ensure that there is enough information available to initiate a proper analysis.

It is important to remark that this guideline is not exhaustive, it can be expanded as more research and trends become available. Therefore, it is suggested that more efforts are put towards analysing what are the elements that make employment areas successful and studying ways to create policies that promote these elements to strengthen the resilience of these areas. Finally, it is recommended that the guideline is revised to incorporate changes in employment and industry trends to ensure that it remains updated.

This type of decisions can not be taken by a mobile application. Every city has different values and ways of thinking. Although it may be tempting to recommend using computerized methods to assign weights to aspects of the guideline, it would be simplistic to think that such model would apply to every geography. Actually, complex planning decisions of this sort can not be delegated to a computer but weighting could help shifting the balance to those aspects that each community considers more important in their decision making process.

Views of the author about the importance of employment areas have changed to a more balanced perspective. The author gives more consideration to the need of a variety of employments to people from different levels of education, not only because this could represent a stronger tax base but also because it would prevent more people falling into poverty. This also brings economic prosperity and resilience because while economic downturns could bring impacts to the economy, having a diverse industry and workforce will ease the impact that this downturn could have (City of Toronto, 2013). However, efforts should be made to prioritize and attract those companies that have the best potential to improve the city's revenue. This could be done through incentives and investment in skills development. 
It is definitely important to provide land for residential uses but it must not come at the expense of a healthy or potentially thriving industrial area. More efforts should be directed to create complete communities in other places and achieve a gentle density to divert the attention that these sites draw as a result of a lack of serviced land to develop housing. Ultimately, the decision of land conversions depends on how much value the City of Toronto gives to the employment areas, how neighbors perceive a proposed developments and how the owner is able to defend his or her interests. 


\section{Appendix A}

\section{Guideline to evaluate proposals}

1. Is the site in proximity to areas that could cause nuisance such as highways and manufacturing plants?

2. Is there buffering from industrial areas or nuisance generating areas

3. Is the area contaminated or exposed to other sources of contamination?

4. Is the proposal compliant with noise, emissions, odours and vibration standards?

5. Is a portion of the proposal inside a flood plain?

6. Does the proposal conform with employment land preservation policies?

7. Is the site is surrounded by other employment uses?

8. Is the site part of a larger employment area?

9. Is the proposal within an employment area or within an employment district?

10. Does the proposal affect a pocket of employment lands and jobs within the area?

11. Does the proposal affect the viability of the larger employment area?

12. Is the proposal in one of the few available employment areas?

13. Will the proposal influence employment job growth forecast?

14. Will the proposal reduce manufacturing jobs but preserve or increase other types?

15. Does the proposal maintain or increases employment uses?

16. Will the proposal add non residential area for employment usage?

17. Did the area have traditional industrial usage?

18. Is the area attractive for employment uses?

19. Is the site visible from the road?

20. Is the proposal consistent with adjacent uses?

21. Is there a need to convert this employment area to meet population growth targets?

22. Could this proposal encourage more conversions in the future?

23. Could this employment area be affordable for small or new starting companies? 
24. Would non industrial uses be exposed to risk from truck traffic?

25. Would the proposal generate excessive traffic?

26. Are there secondary policies for residential uses in adjacencies of the proposal area?

27. Is the proposal in proximity to a residential area?

28. What is the site's relationship with adjacent community or areas?

29. Does the proposal comply with secondary plans and design guidelines?

30. Does the proposal include a mix of housing forms?

31. Is the proposed development in accordance with requirements of block design, orientation, density, built form, massing, height, shadows and design?

32. Is the proposal isolated from a larger employment area?

33. Is there residential development occurring in the area?

34. Were there similar residential developments approved in the past?

35. Does the proposal promote creation of restaurants, recreation and entertainment facilities?

36. Does the proposal discourage large retail stores?

37. Does the proposal play an important cultural role in the neighborhood?

38. Is there affordable housing considered within the proposal?

39. Does the proposal improve streetscape and public realm?

40. Is the proposal compliant with local and provincial planning documents?

41. Are there any cross jurisdictional issues?

42. Will the proposal impact adjacent heritage properties?

43. Is there community infrastructure to support the proposal?

44. Is the site adjacent to major transportation routes? (Highways, rail, airports and sea ports)

45. Is the site covered by transit?

46. What is the status of the access roads?

47. Is there any parkland dedication near the site?

48. If a mixed use development is approved, will the non residential buildings be built first? 
49. does the proposal consider uses that provide services to the city? (snow removal, garbage collection, among others)

50. Is the site close to an area where important research is being done?

51. Is the site in proximity to a central business district?

52. Is the site infrastructure capable to support the proposed development?

53. Are there buildings in the site that could be re-used or refurbished?

54. Is there any interest in the site by industrial or commercial businesses? 


\section{References}

Alamenciak, T. (2012, September 27). Condos and the chocolate factory: Nestlé Canada wages campaign against development. Toronto Star Newspapers Ltd. Retrieved from https://www.thestar.com/news/gta/2012/09/27/condos_and_the_chocolate_factory_nestl_ca nada_wages_campaign_against_development.html

Amborski, D. (2016). Affordable Housing and Land Supply Issues In The Greater Toronto Area (GTA). Toronto: Centre for Urban Research and Land Development.

Avison Young. (2016). Greater Toronto Area Industrial Market Report - 1st Quarter 2016. Toronto: Avison Young.

Banfield, E. (1959). Ends and Means in Planning. International social Science Journal, XI(3).

Burchell, R., \& Listokin, D. (1992). Fiscal impact procedures - State of the Art . New Brunswick: Center for Urban Policy Research - Rutgers, the State University.

City of Toronto. (2000). by Law No 304-33, Class 1 Industrial Zone.

City of Toronto. (2013). A Strategic Plan for Accelerating Economic Growth and Job Creation in toronto. Toronto: City of Toronto.

City of Toronto. (2013). Economic Value of the City's Employment Lands. Toronto: City of Toronto.

City Of Toronto. (2013). Mr.Christie's Site Working Group - Meeting 2 Summary: Drawing Upon the Experts . Toronto: City of Toronto.

City of Toronto. (2013, October 29). Working Group Results for the Mr. Christie's Site at 2150 Lake Shore Boulevard West and 23 Park Lawn Road. Toronto.

City of Toronto. (2014). 2011 National Household Survey - Ward 6 Etobicoke-Lakeshore. Toronto: City of Toronto.

City of Toronto. (2014). City of Toronto Ward Profiles - 2011 Census Ward 6 Etobicoke-Lakeshore. Toronto: City of Toronto.

City of Toronto. (2014). Conversion Requests. Toronto: City of Toronto.

City of Toronto. (2015). Toronto Official Plan. City of Toronto.

City of Toronto. (2015). Economic Dashboard - Annual summary, 2015. Toronto: City of Toronto.

City of Toronto. (2016, October 16). Retrieved from City Planning - Zoning Bylaw 569-2013: http://www1.toronto.ca/wps/portal/contentonly?vgnextoid=2a8a036318061410VgnVCM10000 071d60f89RCRD

City of Toronto. (2016). Economic Indicators. Toronto: City of Toronto. 
City of Toronto. (2016, October 16). Key Industry Sectors. Retrieved from Toronto: http://www1.toronto.ca/wps/portal/contentonly?vgnextoid=401132d0b6d1e310VgnVCM10000 071d60f89RCRD

City of Toronto. (2016, October 16). Zoning Bylaw 569-2013. Retrieved from http://www1.toronto.ca/wps/portal/contentonly?vgnextoid=2a8a036318061410VgnVCM10000 071d60f89RCRD

City Planning . (2014, March 17). Preliminary Report . Toronto: City of Toronto.

Clayton , F. (2015). Why There is a Shortage of New Ground-Related Housing in the GTA. Toronto : Centre for Urban Research and Land Development.

Clayton, F. (2015). Warden Woods: A Case Study of Building Affordable Market Housing on Former Industrial Lands. Toronto: Centre for Urban Research and Land Development.

Clinkard, J. (2017, February 2). Economic Commentary: Greater Golden Horseshoe Resale Housing Market Trends. Retrieved from Centre for Urban Research and Land Development: http://www.ryerson.ca/cur/publications/EconomicCommentaries/resalehousingq4/

Cogliano, D. (2012, p.24). Punching Out: Exploring Justifications for Employment Land Conversions in the GTA. 24. Toronto: Ryerson University.

Economic Development and Parks committee. (2006). Long Term Strategy for Retaining Employment Lands and Stimulating New Investment and Job Creation. Toronto: City of Toronto.

Ellen, I. G., Yager, J., Hanson, M., \& Bosher, L. (2016). Planning for an Uncertain Future: Can Multicriteria Analysis Support Better Decision Making in Climate Planning? Jpournal of Planning Education and Research .

Federation of Canadian Municipalities. (2016). Reusing Industrial Sites for Residential Development: A Municipal Planning Review Procedure - 16 Step Review Procedure for Industrial to Residential Conversions: Official Plan and Zoning Amendments. Toronto : Federation of Canadian Municipalities .

Flyvbjerg, B. (2006). Five misunderstandings about case-study research. Qualitative Inquiry, 219-245.

Glaeser, E. L. (2007). Agglomeration Economics. Chicago: The University of Chicago Press.

Grant, T. (2011, May 27). Red Path Sugar is staying put, condos be damned. The Globe and Mail. Retrieved from http://www.theglobeandmail.com/news/toronto/redpath-sugar-is-staying-putcondos-be-damned/article598354/

Green Leigh, N., \& Hoelzel, N. (2012). Smart Growth's Blind Side . Journal of the American Planning Association, 78(1), 87-103.

Harrington , J., \& Warf, B. (1995). Industrial location: Principles, practice and policy. New York: Routledge.

Hindle , T. (2008). The Economist Guide to Management Ideas and Gurus. London: Economist Books. 
Hirsch, W. (1964). Fiscal impact of industrialization on local schools. The Review of Economics and Statistics, 191-199.

Howland, M. (2010). Planning for industry in a post-industrial world: Assessing industrial land in a suburban economy. ournal of the American Planning Association, 39-53.

Hsieh, H.-F., \& Shannon, S. (2005). Three approaches to qualitative content analysis. Qualitative Health Research, 15(9), 1277-1288.

J.C. Williams Group Limited. (2014). Evaluating Large Retail Developments Near Pedestrian Shopping Areas in Toronto. Toronto: J.C. Williams Group .

John P., B., \& Premus, R. (1987). Major factors in industrial location: A review. Economic Development Quarterly, 1(1), 72-85.

Karakaya , F., \& Canel , C. (1998). Underlying Dimensions of Business Location Decisions. Industrial Management and Data Systems , 321-329.

Lester, W., Kaza, N., \& Kirk, S. (2013). Making Room For Manufacturing: Understandng Industrial Land Coversion in Cities. Journall of the American Planning association, 295-313.

Malone Given Parsons Ltd. (2012). Sustainable Competitive Advantage and Prosperity - Planning for Employment Uses in the City of Toronto. Toronto: Malone Given Parsons Ltd.

McGinnis, R. (2012, November 21). The End of the Lake Shore Motel Strip. Retrieved from blogTO Web Site: http://www.blogto.com/city/2012/11/the_end_of_the_lakeshore_motel_strip/

Moffat, M. (2016, October 16). Reforging Ontario. Retrieved from Literary Review of Canada: http://reviewcanada.ca/magazine/2014/12/reforging-ontario/

Ontario. (1956). The Planning Act, 1955: Statutes of Ontario, 1955, chapter 61, as amended by Statutes of Ontario, 1956, Chapter 64. Toronto: Community Planning Branch, Dept. of Planning and Development.

Ontario. (2006). Growth Plan for the Greater Golden Horseshoe. Ministry of Infrastructure.

Ontario. (2014). Provincial Policy Statement, 2014. Ministry of Municipal Affairs and Housing.

Ontario Ministry of Finance. (2012, June 12). 2011 Census Highlights: Factsheet 1. Retrieved from Ontario Ministry of Finance Website:

http://www.fin.gov.on.ca/en/economy/demographics/census/cenhi11-1.html

Pagliaro, J. (2012, November 1). Mr. Christie's Bakery in Etobicoke set to close, throwing 550 out of work. Toronto Star Newspapers.

Porter, M. E. (1995). The competitive advantage of the inner city. Harvard Business Review , 55-71.

PwC. (2016). Cities of Opportunity 7. Toronto: PwC.

Smith, P. (2013). November 21 Special Public Meeting- Five Year Official Plan Review/Municipal Comprehensive Review. 23 Park Lawn Road and 2150 Lake Shore Boulevard West. Toronto: Bousfields INC. 
Statistics Canada. (2017, February 23). Census Profile, 2016 Census. Retrieved from Statistics Canada: https://www12.statcan.gc.ca/census-recensement/2016/dp-pd/prof/index.cfm?Lang=E

The Economist . (2016, November 06). Retrieved from The World's most liveable cities: http://www.economist.com/blogs/graphicdetail/2016/08/daily-chart-14

Toronto Real Estate Board. (2016). Commercial Realty Watch. Toronto: Toronto Real Estate Board.

Toronto Real Estate Board. (2017). Market Watch - January 2017. Toronto: Toronto Real Estate Board.

Wong , J. (2004). The fiscal impact of economic growth and development on local government revenue capacity. Journal of Public Budgeting, Accounting \& Financial Management , 16(3), 413.

Yin, R. (1981). The case study as a serious research strategy. Knowledge, 3(1), 97-114. 